\title{
Synthesis of Li and Mn-rich layered oxides as concentration-gradients for Lithium-ion batteries
}

\author{
Ségolène Pajot ${ }^{\mathrm{a}, \mathrm{b}, \mathrm{c}}$, Pierre Feydi ${ }^{\mathrm{b}, \mathrm{c}}$, François Weill ${ }^{\mathrm{a}}$, Michel Ménétrier ${ }^{\mathrm{a}}$, \\ Gunay Yildirim ${ }^{\mathrm{b}}$, Loïc Simonin ${ }^{\mathrm{c}}$ and Laurence Croguennec ${ }^{\mathrm{a}, \mathrm{d}, \mathrm{e}, *}$ \\ a ICMCB-CNRS, Univ. Bordeaux, Bordeaux INP, 87 avenue du Dr Schweitzer, ICMCB UMR 5026, \\ F-33600 Pessac, France. \\ ${ }^{b}$ Univ. Grenoble Alpes, F-38000 Grenoble, CEA, LITEN, 17 rue des Martyrs, \\ F-38054 Grenoble cedex 9, France. \\ ${ }^{c}$ CEA Tech Aquitaine. Bordeaux, 16 avenue Pey Berland - F-33607 Pessac, France \\ ${ }^{d}$ RS2E, Réseau Français sur le Stockage Electrochimique de l'Energie, \\ FR CNRS 3459, F-80039 Amiens Cedex 1, France \\ ${ }^{e}$ ALISTORE-ERI European Research Institute, FR CNRS 3104, F-80039 Amiens Cedex 1, France
}

\begin{abstract}
$\mathrm{Li}$ and $\mathrm{Mn}$-rich layered oxides, i.e. $\mathrm{Li}_{1+\mathrm{x}} \mathrm{M}_{1-\mathrm{x}} \mathrm{O}_{2}(\mathrm{M}=\mathrm{Mn}, \mathrm{Ni}$ and $\mathrm{Co})$, are attractive positive electrode materials for Li-ion batteries due to their promising high specific capacities. Unfortunately, these materials provide an energy-density fading due to a continuous voltage decay resulting from chemical instability of their surface structure upon cycling. The purpose of this paper is to discuss the main insights got from syntheses of materials targeted to be concentration-gradients of global compositions $\mathrm{Li}_{1+\mathrm{x}}\left(\mathrm{Mn}_{0.47} \mathrm{Ni}_{0.26} \mathrm{Co}_{0.17}\right)_{1-\mathrm{x}} \mathrm{O}_{2}$ with: (i) $\mathrm{Li}$ and $\mathrm{Mn}$-rich layered oxides in the core to deliver high capacity, and (ii) layered oxides enriched in $\mathrm{Ni}$ and in Co moving to the surface of the spherical aggregates to promote improved chemical and thermal stability for the electrode material. Concentration-gradient, core-shell or re-homogenized materials were obtained depending on the temperature and excess of lithium used for the high temperature thermal treatment (i.e. the second step of the synthesis). Despite complex to master, the engineering of layered oxide materials was shown to be a track to follow to optimize the performance of an electrode material.
\end{abstract}

${ }^{*}$ Corresponding author (L. Croguennec): Laurence.Croguennec@icmcb.cnrs.fr 
Pajot et al., submitted to JES

\section{Introduction}

Batteries with ever higher energy densities are required for energy storage for portable electronic devices, electric and hybrid vehicles and renewable energies produced from sun, wind or waves. Lithium-ion batteries have been used for portable devices for more than two decades and they remain the favorite candidates for most of the applications. Among all the possible alternatives as positive electrode materials, the $\mathrm{Li}$ and $\mathrm{Mn}$-rich layered oxides $\mathrm{Li}_{1+\mathrm{x}} \mathrm{M}_{1-\mathrm{x}} \mathrm{O}_{2}(\mathrm{M}=\mathrm{Mn}, \mathrm{Ni}$ and $\mathrm{Co})$ currently attract, with the high voltage spinel oxides such as $\mathrm{LiNi}_{1 / 2} \mathrm{Mn}_{3 / 2} \mathrm{O}_{4}$, a strong interest in the scientific community. Indeed, the $\mathrm{Li}$ and $\mathrm{Mn}$-rich layered oxides exhibit very high reversible capacities (around $250 \mathrm{mAh} / \mathrm{g}$ ), at an affordable cost. ${ }^{1-3}$ A common feature for all these oxides is their long voltage "plateau" (i.e. high capacity), observed only during the second part of the first charge. This behavior has been associated to the reversible participation of oxygen anions in the redox processes. ${ }^{4}$ While it is clear that the largest advantage of the Li-rich layered oxides lies in their outstanding capacities, they suffer from a continuous voltage decay upon cycling. ${ }^{5-6}$ This is induced by irreversible structural modifications occurring at the outer part of the particles (that determines the potential measured) and giving rise to densification of the metal-oxygen framework..$^{7-9}$ One of the tracks we are following to modify the surface chemistry of the $\mathrm{Li}$ and Mn-rich layered oxides towards a better stabilization of the anionic redox, and to create synergies between properties (for instance, energy density and thermal stability), is the formation of concentration gradients within the spherical aggregates. The goal is to promote the formation of the $\mathrm{Li}$ and Mn-rich layered oxides in the bulk and, moving to the surface, to enrich the layered oxides composition in $\mathrm{Ni}$ and $\mathrm{Co}$ : the target is to combine high energy density and chemical stability as was reported for Ni-rich layered oxides. ${ }^{10-14}$

A full concentration-gradient carbonate $\mathrm{Ni}_{0.29} \mathrm{Mn}_{0.53} \mathrm{Co}_{0.18} \mathrm{CO}_{3}$ was synthesized as a precursor, and the corresponding positive electrode materials $\mathrm{Li}_{1+\mathrm{x}}\left(\mathrm{Ni}_{0.29} \mathrm{Mn}_{0.53} \mathrm{Co}_{0.18}\right)_{1-\mathrm{x}} \mathrm{O}_{2}$ were obtained at different temperatures $\left(700^{\circ} \mathrm{C}, 800^{\circ} \mathrm{C}\right.$ and $900^{\circ} \mathrm{C}$ ) and with different lithium excesses (i.e. $\mathrm{x}=0,0.05$ and 0.20 ). Their composition, structure, morphology and electrochemical performance will be discussed in detail in the following, in comparison with those of a homogeneous material with the composition of the core of the aggregates, $\mathrm{Li}_{1.2} \mathrm{Ni}_{0.2} \mathrm{Mn}_{0.6} \mathrm{O}_{2}$. The aim of this paper is first to highlight that the mastering of the concentration-gradients is complex. High temperature is required to form a Li-rich layered oxide with a lithium-transition metal ordering in the slabs to promote the most efficient reversible oxygen redox and high capacity. But, in parallel, high temperature promotes also cation diffusion within the bulk and thus compete intrinsically with the formation of a gradient. This paper supports also that the formation of core-shell layered oxide materials is a track of optimization of the properties of an electrode material. 


\section{Experimental}

To synthesize the conventional Lithium-rich layered oxide material $\mathrm{Li}_{1.2} \mathrm{Mn}_{0.6} \mathrm{Ni}_{0.2} \mathrm{O}_{2}$ (i.e. showing a homogeneous distribution of the cations within the aggregates, from the surface to the bulk), $\mathrm{MnSO}_{4} \cdot \mathrm{H}_{2} \mathrm{O}$ (Sigma-Aldrich, < $99 \%$ ) and $\mathrm{NiSO}_{4} \cdot 6 \mathrm{H}_{2} \mathrm{O}$ (Sigma-Aldrich, $99 \%$ ) are used as precursors to prepare the mixed transition metal carbonate $\mathrm{Ni}_{0.25} \mathrm{Mn}_{0.75} \mathrm{CO}_{3}$ by the co-precipitation method. An aqueous mixed solution of $\mathrm{MnSO}_{4} \cdot \mathrm{H}_{2} \mathrm{O}$ and $\mathrm{NiSO}_{4} \cdot 6 \mathrm{H}_{2} \mathrm{O}(0.75: 0.25 \mathrm{in}$ molar ratio) with a total transition metal ion concentration of $2 \mathrm{~mol} / \mathrm{L}$ was pumped slowly into a continuously stirred reactor (CSTR). At the same time, a $1.8 \mathrm{~mol} / \mathrm{L}$ aqueous solution of $\mathrm{Na}_{2} \mathrm{CO}_{3}$ (Sigma-Aldrich, $\geq 99.5 \%$ ), used as precipitant, and the required amount of $\mathrm{NH}_{4} \mathrm{OH}$ (J.T Baker, 28-30 \%) aqueous solution used as chelating agent, were separately fed into the reactor in order to maintain the $\mathrm{pH}$ value at 7.5 . The temperature was kept at $50^{\circ} \mathrm{C}$ during the overall reaction and the final solution was aged for $7 \mathrm{hrs}$. Afterward, the conventional carbonate was recovered by filtration, washed several times with hot water in order to remove residual sodium and sulfate species, and finally dried overnight in an oven at $80^{\circ} \mathrm{C}$. To obtain the final conventional Lithium-rich layered oxide $\mathrm{Li}_{1.2} \mathrm{Mn}_{0.6} \mathrm{Ni}_{0.2} \mathrm{O}_{2}$, the carbonate was intimately mixed with an excess $(5 \%)$ of lithium carbonate $\left(\mathrm{Li}_{2} \mathrm{CO}_{3}\right.$ (Alfa Aesar, $\left.\left.99 \%\right)\right)$ and the mixture was fired in air at $900^{\circ} \mathrm{C}$ during 24 hrs. ${ }^{15-16}$

To prepare a Lithium-rich layered oxide material exhibiting a cation concentration-gradient within its aggregates, it is necessary to synthetize first a carbonate with a concentration-gradient. Figure 1 shows the experimental setup used for the co-precipitation process. We chose to enrich the composition in $\mathrm{Ni}$ and in $\mathrm{Co}$ (vs. Mn) all along the reaction, starting with the composition $\mathrm{Ni}_{0.25} \mathrm{Mn}_{0.75} \mathrm{CO}_{3}$ within the bulk of the carbonate. Only the differences with the synthesis just described above will be mentioned hereafter. $\mathrm{MnSO}_{4} \cdot \mathrm{H}_{2} \mathrm{O}, \mathrm{NiSO}_{4} \cdot 6 \mathrm{H}_{2} \mathrm{O}$ and $\mathrm{CoSO}_{4} \cdot 7 \mathrm{H}_{2} \mathrm{O}$ (Sigma-Aldrich, $\geq 99 \%$ ) were used as precursors. The aqueous solution of $\mathrm{MnSO}_{4} \cdot \mathrm{H}_{2} \mathrm{O}$ and $\mathrm{NiSO}_{4} \cdot 6 \mathrm{H}_{2} \mathrm{O}$ (0.75:0.25 in molar ratio), with a total transition metal ion concentration of $2 \mathrm{~mol} / \mathrm{L}$, corresponds to solution $\mathrm{A}$ in Figure 1. The aqueous solution of $\mathrm{MnSO}_{4} \cdot \mathrm{H}_{2} \mathrm{O}, \mathrm{NiSO}_{4} \cdot 6 \mathrm{H}_{2} \mathrm{O}$ and $\mathrm{CoSO}_{4} \cdot 7 \mathrm{H}_{2} \mathrm{O}(1: 1: 1$ in molar ratio), with a total transition metal ion concentration of $2 \mathrm{~mol} / \mathrm{L}$, corresponds to solution B. At the beginning of the synthesis, solution A was pumped into the CSTR reactor and was stirred at $200 \mathrm{rpm}$. After a few minutes, solution B was pumped into solution A in order to change continuously its concentration in transition metal ions before it was injected into the reactor. Similarly to what was described before, the $\mathrm{pH}$ was maintained at 7.5 during the overall reaction, the temperature at $50^{\circ} \mathrm{C}$ and the solution aged for 7 hrs. To obtain the lithiated oxide materials, the recovered concentration-gradient carbonate was intimately mixed with lithium carbonate $\left(\mathrm{Li}_{2} \mathrm{CO}_{3}\right)$. Different thermal treatments were performed with the initial goal to obtain layered oxide materials with concentration-gradients: different temperatures were used $\left(700^{\circ} \mathrm{C}, 800^{\circ} \mathrm{C}\right.$ and $\left.900^{\circ} \mathrm{C}\right)$ as well as different excesses of lithium (0\%, 5\% and 20\%). 
The chemical composition of the supernatants, of the carbonates and of the lithiated oxides was evaluated using inductively coupled plasma/optical emission spectrometry (ICP-OES) after their complete dissolution into a mixture of hydrochloric and nitric acids; this allows determining the $\mathrm{Li}, \mathrm{Ni}$, $\mathrm{Mn}$ and Co contents within the solutions and powders, the absolute error was estimated to be $3 \%$. As oxygen could not be titrated, the relative chemical composition of the lithiated materials will be given considering the cations only. TGA analyses were performed using a commercial TA instruments Q600 to get more insight into the decomposition temperature of the carbonate and to determine the corresponding mass loss and thus the composition and purity of the powder. The TGA analysis was performed under air, at a heating rate of $2^{\circ} \mathrm{C} / \mathrm{min}$ up to $900^{\circ} \mathrm{C}$ and with $7 \mathrm{hrs}$ at $900^{\circ} \mathrm{C}$, and a cooling rate of $20^{\circ} \mathrm{C} / \mathrm{min}$. The crystalline phases present in the prepared materials were identified by X-ray diffraction (XRD) using a PANalytical X'Pert MPD Pro diffractometer in the [10-80 $\left.2 \theta_{\mathrm{cu}}\right]$ angular range, with steps of $0.016^{\circ}$ and a total acquisition time of $34 \mathrm{~min}$. Refinement of the XRD data was performed by the Le Bail method using the Fullprof software, and considering the presence of two phases when required. The morphological features and particles sizes were observed by scanning electron microscopy (SEM, Jeol 6700F microscope). The powders were previously metallized by gold deposition.

The cross-section of the electrodes containing the concentration-gradient materials was performed with a cross section polisher (llion+ll model 697 Gatan) and the changes in $\mathrm{Ni}, \mathrm{Mn}$ and Co compositions were examined along different lines across the section with an electron microbeam probe (CAMECA SX 100). The samples were prepared by mixing the active materials with the conductive additive Super $\mathrm{P}$ carbon and the binder polyvinylidene fluoride (PVdF) (80:10:10 wt.\%) in the solvent N-methyl-2pyrrolidone; the slurry was cast on an aluminum foil to obtain an electrode and in fact a rigid sample. These electrodes were fixed on a titanium holder and were then introduced into the cross section polisher. The polishing was carried out during $2 \mathrm{hrs}$ at $5 \mathrm{kV}$ and the cleaning during $30 \mathrm{~min}$ at $1 \mathrm{kV}$ in a continuous flow of argon ions. The cross-section of the samples was examined with the electron microbeam probe with a voltage of $12 \mathrm{kV}$ and a current of $20 \mathrm{nA}$.

The electrochemical tests were performed using coin type R2032 cells that consisted of a positive electrode and of a lithium foil as negative electrode, separated by a Celgard ${ }^{\circledR} 2400$ porous polypropylene film and a Viledon ${ }^{\circledR}$ separator. The positive electrodes were prepared by coating a slurry made of the mixture of the active material, Super P carbon and PVdF (80:10:10 wt.\%) in N-methyl-2-pyrrolidone on an aluminum foil. The electrolyte was $1 \mathrm{~mol} / \mathrm{L} \mathrm{LiPF}_{6}$ dissolved in a mixture of ethylene carbonate (EC), propylene carbonate (PC), and dimethyl carbonate (DMC) in a 1/1/3 volume ratio. The coin cells were assembled in an argon-filled glove box and were cycled using a VMP (Biologic) in galvanostatic mode. Charge and discharge were performed at the rate of $\mathrm{C} / 10$ in the voltage range of $2.5 \mathrm{~V}-4.8 \mathrm{~V}$ or $2.5 \mathrm{~V}-4.55 \mathrm{~V}$ at room temperature (C corresponding to the theoretical exchange of one electron in 1 hr). 


\section{Results and discussion}

\section{2a. More insights into the synthesis process by coprecipitation}

In order to be critical on the synthesis of the carbonates showing a concentration-gradient, and especially on the completeness of the precipitation of all the species when introduced within the reactor under stirring, we compared the theoretical transition metal compositions with those determined experimentally. The change in the concentration of transition metals in solution A is defined as given in equations (1) and (2):

$$
\left.\frac{d\left(C_{a} V\right)}{d t}=Q_{b} C_{b}-Q_{a} C_{a} \quad \text { (eq. } 1\right) \quad \text { and } \quad \frac{d}{d t}\left(C_{a}\right)=\frac{Q_{b} C_{b}}{V}-\frac{Q_{a} C_{a}}{V}
$$

$\mathrm{Q}_{\mathrm{a}}, \mathrm{C}_{\mathrm{a}}, \mathrm{Q}_{\mathrm{b}}, \mathrm{C}_{\mathrm{b}}, \mathrm{t}$ and $\mathrm{V}$ being respectively, the feeding rate of solution $\mathrm{A}$ into the reactor $(\mathrm{ml} / \mathrm{min})$, the concentration of transition metals in solution A when fed into the reactor $(\mathrm{mol} / \mathrm{L})$, the feeding rate of solution B into solution A $(\mathrm{ml} / \mathrm{min})$, the transition metals concentration in solution $B(\mathrm{~mol} / \mathrm{L})$, the duration time ( $\mathrm{min}$ ) and the volume of solution $\mathrm{A}$ in the tank $(\mathrm{ml})$, that latter being constant when adding solution B. The concentration of each transition metal $\mathrm{x}$ in the solution, as function of time, when just fed into the reactor is thus defined by equation (3):

$$
C_{a x}(t)=\left(C_{a x}(0)-C_{b}\right) e^{-\frac{Q a}{V}(t-\delta t)}+C_{b} \quad \text { (eq. 3) }
$$

Figure 2 gives the evolution of the molar fraction of $\mathrm{Ni}, \mathrm{Mn}$ and $\mathrm{Co}$ in solution A during the reaction. The molar fractions at $\mathrm{t}=0\left(\mathrm{t}_{\mathrm{m}} \mathrm{Ni}=0.25 ; \mathrm{t}_{\mathrm{m}} \mathrm{Mn}=0.75 ; \mathrm{t}_{\mathrm{m}} \mathrm{Co}=0\right)$ give the composition of the carbonate at the center of the aggregates $\left(\mathrm{Ni}_{0.25} \mathrm{Mn}_{0.75} \mathrm{CO}_{3}\right)$. After a delay of few minutes, solution $\mathrm{B}\left(\mathrm{t}_{\mathrm{m}} \mathrm{Ni}=1 / 3\right.$; $\mathrm{t}_{\mathrm{m}} \mathrm{Mn}=1 / 3 ; \mathrm{t}_{\mathrm{m}} \mathrm{Co}=1 / 3$ ) was introduced continuously in solution A. Assuming that the reaction is total and instantaneous, the expected composition of the carbonate at the surface of the aggregates is $\mathrm{Ni}_{0.32} \mathrm{Mn}_{0.41} \mathrm{Co}_{0.27} \mathrm{CO}_{3}$, whereas their average theoretical composition would be $\mathrm{Ni}_{0.295} \mathrm{Mn}_{0.525} \mathrm{Co}_{0.182} \mathrm{CO}_{3}$. Chemical analyses were performed by ICP-OES all along the reaction to confirm theses changes in composition, and they were found to be in good agreement with equation (3).

As an example, chemical analyses of the supernatant and of the carbonate, both recovered at the end of the reaction, are given in Table 1 and compared to the expected values. Less than 1\% of Mn, Co and Ni remain in the supernatant at the end of the reaction, showing that all the transition metal ions precipitate during the reaction. Furthermore the average transition metals composition of the powder is $\mathrm{Ni}_{0.29} \mathrm{Mn}_{0.53} \mathrm{Co}_{0.18}$ considering the results reported in Figure 2. This chemical composition was fully determined by TGA analysis, considering - as shown in Table 1 - the loss of $36 \mathrm{wt} . \%$ and the carbonate decomposition reaction $\left[\mathrm{MCO}_{3}+1 / 6 \mathrm{O}_{2} \rightarrow 1 / 3 \mathrm{M}_{3} \mathrm{O}_{4}+\mathrm{CO}_{2}\right]$. Indeed, the formation of $\mathrm{M}_{3} \mathrm{O}_{4}$ was shown 
Pajot et al., submitted to JES

by XRD. The experimental weight loss is in agreement with the quantity of carbon dioxide expected to be released. The consistency between the experimental analyses and theory allows to confirm definitely the average carbonate composition as $\mathrm{Ni}_{0.29} \mathrm{Mn}_{0.53} \mathrm{Co}_{0.18} \mathrm{CO}_{3}$.

\section{2b. The nature of the materials formed}

Figure 3a shows the XRD pattern recorded for the as prepared concentration-gradient carbonate; all the diffraction lines can be indexed in a rhombohedral unit cell described in the $\mathrm{R} \overline{\mathrm{c}} \mathrm{c}$ space group. The line width is around $0.74^{\circ}$, suggesting the formation of crystalline domains being $130 \AA$ in size. Figure $3 \mathbf{b}-\mathbf{c}$ shows the corresponding SEM images. The low-magnification image reveals the formation of spherical aggregates with a diameter around $10 \mu \mathrm{m}$ (Figure 3b), whereas the high-magnification image shows that each aggregate is composed of primary particles of few nanometers (Figure 3c). EPMA analysis was performed on aggregates polished in section as shown in Figure 4a; a large number of aggregates was analyzed and similar results were obtained from one aggregate to another. As illustrated in Figure $\mathbf{4 b}$, the atomic percentages of $\mathrm{Mn}, \mathrm{Ni}$ and $\mathrm{Co}$ were determined moving from one side of the aggregate to the opposite side. A clear evidence for the presence of concentration-gradient in transition metals was demonstrated, with an increasing content in Mn from the surface to the center and conversely a decreasing content in $\mathrm{Ni}$ and in Co. Changes in the transition metal concentrations are continuously observed within a shell being $4 \mu \mathrm{m}$ in thickness. At the center of the aggregate, the composition in metals is $\mathrm{Ni}_{0.11} \mathrm{Mn}_{0.86} \mathrm{Co}_{0.03}$, whereas at the surface it is $\mathrm{Ni}_{0.30} \mathrm{Mn}_{0.50} \mathrm{Co}_{0.20}$. A core of $4 \mu \mathrm{m}$ diameter is thus obtained, in good agreement with the addition of solution B delayed from 30 min. The EPMA measurement error is estimated to be $1 \%$ when one considers a material with an ideal "zero-defect" surface and a high concentration for the element analyzed, but for a material such as the concentrationgradient carbonate formed as spherical aggregates with grain boundaries the measurement error is much higher.

Figure 5a shows the XRD patterns recorded for the concentration-gradient lithiated layered oxides calcined at $700^{\circ} \mathrm{C}, 800^{\circ} \mathrm{C}$ and $900^{\circ} \mathrm{C}$ with an excess of $0 \%, 5 \%$ and $20 \%$ of lithium. The materials obtained will be hereafter referred to this temperature and this excess of lithium, for instance the material obtained at $900^{\circ} \mathrm{C}$ with an excess of $0 \%$ is named $900^{\circ} \mathrm{C}-0 \%$. The XRD pattern of the conventional layered oxide $\mathrm{Li}_{1.2} \mathrm{Mn}_{0.6} \mathrm{Ni}_{0.2} \mathrm{O}_{2}$ is also given for comparison. All the main diffraction lines observed for the ten XRD patterns can be indexed in unit cells described in the $\mathrm{R} \overline{3} \mathrm{~m}$ space group and typical of a layered oxide structure. The presence of extra broader peaks in the angular range $20^{\circ}-25^{\circ}(2 \theta)$ confirms the formation of lithium-rich layered oxides with the presence of extra lithium ions in the transition metal sites and a tendency to a cationic ordering. ${ }^{17-20}$ However, as highlighted in the enlargement given in Figure 5b, for the samples calcined with $0 \%$ of excess lithium, additional peaks were observed and associated to the formation of a spinel phase whose unit cells are described in the $F d \overline{3} m$ space group. 
The lithium loss occurring at the surface of the particles during the calcination at high temperature induces a non-stoichiometry in lithium and thus the formation of the spinel-type phase whose structure is close to that of the layered oxide, but with a Li/M ratio smaller than 1 and actually close to $1 / 2$. These XRD patterns highlight also changes in the powder crystallinity and in the structure of the materials depending on the calcination temperature. Table 2 summarized for each sample the full width at half maximum (FWHM) determined for the $(018)_{\mathrm{R}-3 \mathrm{~m}}$ and $(110)_{\mathrm{R}-3 \mathrm{~m}}$ diffraction lines, as well as the intensity ratio for the $(003)_{\mathrm{R}-3 \mathrm{~m}}$ and $(104)_{\mathrm{R}-3 \mathrm{~m}}$ peaks. As expected, the decrease in temperature is accompanied by the broadening of the diffraction lines, including the extra peaks observed between $20^{\circ}$ and $25^{\circ}(2 \theta)$. This broadening can highlight, either the formation of a distribution of isostructural phases very close in composition to form a concentration-gradient, and/or the limited size of the crystalline domains due to the presence of structural defects and phase boundaries within the primary particles. Furthermore, the small values observed for the $\mathrm{I}_{(003) \mathrm{R}-3 \mathrm{~m}} / \mathrm{I}_{(104) \mathrm{R}-3 \mathrm{~m}}$ intensity ratio for materials obtained at $700^{\circ} \mathrm{C}$ show that the layered oxides formed are partially disordered, with the presence of a small amount of transition metal ions in the interslab space (i.e. the Li sites). ${ }^{21-24}$ Note also that an exceptionally high value (such as 1.42 for $900^{\circ} \mathrm{C}-0 \%$ ) is also an evidence of the presence of a spinel-type phase within the material, as the $(111)_{\mathrm{Fd}-3 \mathrm{~m}}$ diffraction line characteristic of the cubic structure merges with the $(003)_{\mathrm{R}-3 \mathrm{~m}}$ diffraction line of the hexagonal layered structure. The values obtained for $\mathrm{I}_{(003) \mathrm{R}-3 \mathrm{~m}} / \mathrm{I}_{(104) \mathrm{R}-3 \mathrm{~m}}$ at $800^{\circ} \mathrm{C}$ and $900^{\circ} \mathrm{C}$ with a lithium excess larger than 5\% strongly suggest the formation of a distribution of 2D layered oxides, in good agreement with the results already reported for the homogeneous layered oxide (LMN). The elementary analyses made by ICP-OES are also gathered in Table 2: first, as expected, the Li/M ratio $(\mathrm{M}=\mathrm{Ni}, \mathrm{Mn}, \mathrm{Co})$ increases with the excess of lithium used during the second step of the synthesis; second, for the materials appearing by XRD to be of layered oxides - type, only a small amount of trivalent nickel $(\leq 3 \%)$ or trivalent manganese $(\leq 13 \%)$ is expected for charge compensation in $\mathrm{Li}_{1+\mathrm{x}} \mathrm{M}_{1-\mathrm{x}} \mathrm{O}_{2}$. Of course, as already largely discussed by some of us, the presence of these trivalent cations will impact the electrochemical properties: they disrupt the cation ordering within the slabs, whereas the ordering between small and large cations as well as the control of the transition metal oxidation states $\left(\mathrm{Ni}^{\mathrm{II}}, \mathrm{Mn}^{\mathrm{IV}}\right.$ and $\left.\mathrm{Co}^{\mathrm{III}}\right)$ are at the origin of an efficient reversible participation of the oxygen anions to the redox processes. ${ }^{27-30}$

Considering that each sample of concentration-gradient type is in fact a distribution of phases, the XRD data were analyzed by the Le Bail method only, in order to determine changes in the lattice parameters depending on the synthesis conditions (temperature and lithium excess): the refinement was performed considering two "phases" for the materials obtained with a $0 \%$ lithium excess (a layered phase and a spinel phase) and a single layered "phase" for the others. Note that in the case of concentration-gradient materials, the use of "phase" is abusive as in fact each "phase" is a distribution of phases close in compositions. The results obtained for the unit cell parameters are given in Table 3. As expected, changes in the lattice parameters are observed. Indeed, the nature of the phases formed (layered only $v s$. 
layered and spinel), the $\mathrm{Li} / \mathrm{M}$ ratio, the oxidation state of the transition metal ions and most probably the extent of the concentration-gradient evolve with the synthesis conditions. The larger the excess of lithium in the materials obtained at $800^{\circ} \mathrm{C}$ and $900^{\circ} \mathrm{C}$, the smaller the cell parameters are, in good agreement with the formation of $\mathrm{Li}$-rich layered oxides $\mathrm{Li}_{1+\mathrm{x}} \mathrm{M}_{1-\mathrm{x}} \mathrm{O}_{2}{ }^{25}$ Note also that as expected for $2 \mathrm{D}$ layered structures, the c/a ratio is larger than 4.90 (i.e. close to 5, 4.90 being the value characteristic for cubic structure). ${ }^{26}$

Figure 6 gives the EPMA analyses performed for six materials calcined at $700^{\circ} \mathrm{C}$ and $800^{\circ} \mathrm{C}$ with different lithium excess, in Figure 6a-c and in Figure 6d-f for the materials calcined at $700^{\circ} \mathrm{C}$ and $800^{\circ} \mathrm{C}$ respectively. At a given temperature, the material evolves from a limited to a more extended concentration-gradient within the aggregates with an increasing lithium excess used during the synthesis. For example, at $700^{\circ} \mathrm{C}$, the shell showing the gradient grows from 2 , to 2.5 and $3 \mu \mathrm{m}$ in thickness with a lithium excess of $0 \%, 5 \%$ and $20 \%$ respectively. A similar trend is observed at $800^{\circ} \mathrm{C}$, with a shell thickness of 1,2 and $3 \mu \mathrm{m}$ for the materials calcined with a lithium excess of $0 \%, 5 \%$ and $20 \%$ respectively. Note that at $900^{\circ} \mathrm{C}$, whatever the excess of lithium, the EPMA analyses have revealed the disappearance of the concentration-gradient resulting from a complete inter-diffusion of the transition metals within the particles and aggregates.

Following this synthesis route, core-shell with a concentration-gradient in the shell and re-homogenized materials were in fact obtained, with different nature: either as spinel - layered composites or as layered only. In the following, our discussions will be focused on the electrochemical performance of the layered only composites.

\section{2c. The electrochemical performance in lithium batteries}

The electrochemical performance obtained in lithium cells for the materials calcined at $700^{\circ} \mathrm{C}, 800^{\circ} \mathrm{C}$ and $900{ }^{\circ} \mathrm{C}$ with excesses of lithium of 5\% and 20\% are compared, in Figure 7 and Table 4, with those obtained for the layered oxide $\mathrm{Li}_{1.2} \mathrm{Mn}_{0.6} \mathrm{Ni}_{0.2} \mathrm{O}_{2}$ ("the reference") calcined at $900^{\circ} \mathrm{C}$. Only the materials obtained as pure layered oxides are discussed hereafter in detail, as their performance can be more directly compared to those of the reference LMN. Nevertheless, more information can be found in Figures S1, S2 and S3 in the supplementary information on the materials obtained with a $0 \%$ excess of lithium, i.e. containing a spinel-type phase next to the layered-type phase. Figure 7a and Table 4 compare the first charge/discharge cycles obtained for the different materials, in the potential window $2.5-4.8 \mathrm{~V} \mathrm{vs} \mathrm{Li}^{+} / \mathrm{Li}$ at a rate of $\mathrm{C} / 10$. For all of them, a plateau typical of the anionic redox activity is observed around $4.5 \mathrm{~V} \mathrm{vs} \mathrm{Li}^{+} / \mathrm{Li}$, shorter in proportion than that observed for $\mathrm{LMN}$ for all the concentration-gradient materials and even shorter when calcined at $700^{\circ} \mathrm{C}$. The plateau being associated to the participation of the oxygen anions to the redox processes, its length depends on the extent of the 
local ordering around the $\mathrm{Li}^{+}$ions present in excess within the slabs, a key feature to promote the reversible anionic redox. Indeed, the more disordered the distribution of the transition metal ions within the slabs and between the slabs and the interslab spaces, the smaller the plateau is as for the materials calcined at $700^{\circ} \mathrm{C} .{ }^{27-29}$ Similarly, the smaller the lithium excess, as it is the case for all the concentrationgradient materials versus LMN (Table 2), the shorter the plateau is. As shown in Figure 7a and Table 4, the initial charge capacity delivered by the $700^{\circ} \mathrm{C}-5 \%$ and $700^{\circ} \mathrm{C}-20 \%$ materials is $274 \mathrm{mAh} / \mathrm{g}$ and $242 \mathrm{mAh} / \mathrm{g}$ respectively, significantly smaller than those delivered by all the other materials $(>286$ $\mathrm{mAh} / \mathrm{g})$.

Figure $7 \mathbf{b}$ gives the evolution of the discharge capacity as function of the cycle number. Note that an activation is observed for all the materials, i.e. an increase of the reversible capacity over the 5 to 10 first cycles. In good agreement with a better control of the composition, structure and cationic ordering at higher temperature, the anionic redox activity and thus the reversible capacity increase. As shown in Table 4, after 60 cycles the materials calcined at $700^{\circ} \mathrm{C}$ deliver a discharge capacity of 123 and 104 $\mathrm{mAh} / \mathrm{g}$ for the $700^{\circ} \mathrm{C}-5 \%$ and $700^{\circ} \mathrm{C}-20 \%$ materials respectively, smaller than that of the materials calcined at $800^{\circ} \mathrm{C}\left(178 \mathrm{mAh} / \mathrm{g}\right.$ for $800^{\circ} \mathrm{C}-5 \%$ and $151 \mathrm{mAh} / \mathrm{g}$ for $\left.800^{\circ} \mathrm{C}-20 \%\right)$ and even much smaller than that of the materials calcined at $900^{\circ} \mathrm{C}\left(215 \mathrm{mAh} / \mathrm{g}\right.$ for $900^{\circ} \mathrm{C}-5 \%, 203 \mathrm{mAh} / \mathrm{g}$ for $900^{\circ} \mathrm{C}-20 \%$ and $220 \mathrm{mAh} / \mathrm{g}$ for $\mathrm{Li}_{1.2} \mathrm{Mn}_{0.6} \mathrm{Ni}_{0.2} \mathrm{O}_{2}(\mathrm{LMN})$ ). The reference $\mathrm{LMN}$ exhibits the highest capacity, considering that the materials synthesized with a 5\% lithium excess (with a shell less extended) produce higher capacities than those obtained with a $20 \%$ lithium excess (with a shell more extended). As shown in Figure 7c and Table 4, the average discharge voltage is higher for the materials calcined at higher temperature, those showing a less extended concentration-gradient but also a more ordered layered structure. Note that whatever the material, the voltage decay associated to oxygen loss and cationic reorganization is observed, more or less pronounced depending on the synthesis conditions. The voltage decay is more mitigated for the materials synthesized at $900^{\circ} \mathrm{C}$, because the more ordered the structure is, the more stable is the cationic distribution versus migration and transformation of layered domains into spinel-type ones.

Considering these first electrochemical results, we could conclude at first sight that the strategy to form engineered composites is not relevant: $(i)$ it does not solve the problem of the voltage decay in Li-rich layered oxides and (ii) it does not improve the reversible capacity and cyclability observed upon long range cycling. Nevertheless, two important points have to be mentioned, and they will be illustrated in the following:

- the voltage window used in Figure $7\left(2.5-4.8 \mathrm{~V} \mathrm{vs} \mathrm{Li}^{+} / \mathrm{Li}\right)$ is not the best option for long range cycling due to the competition between the intrinsic electrode activity and the degradation reaction of the electrolyte at high voltage $(>4.6 \mathrm{~V})$. Furthermore, layered oxides enriched in Ni and in Co (NMC-type) - as the compositions observed at the surface of the aggregates - show 
larger instability at high voltage than Li-rich layered oxides, due to larger volume changes and phase transitions involving slab gliding, ${ }^{31}$ detrimental to the cyclability of the materials.

- the criteria for the optimization of an electrode material are not limited to the reversible capacity and cyclability at an average cycling rate of $\mathrm{C} / 10$. Robustness versus cycling at high rates, at low or high temperatures, etc. are also of importance.

Figure 8 compares the electrochemical performance obtained at $\mathrm{C} / 10$ for the layered oxide type engineered material prepared at $800^{\circ} \mathrm{C}$ with a lithium excess of $5 \mathrm{wt} . \%\left(800^{\circ} \mathrm{C}-5 \%\right)$, in different voltage windows: 2.5 - $4.8 \mathrm{~V}$ vs. $\mathrm{Li}^{+} / \mathrm{Li}$ for all cycles (in black), 2.5 - $4.8 \mathrm{~V}$ only for the first cycle and then 2.5 - $4.55 \mathrm{~V}$ (in blue), or 2.5 - $4.55 \mathrm{~V}$ for all cycles (in red). Figure 8b and Figure 8d highlight especially how detrimental is the cycling in the larger potential window, inducing irreversible reorganization of the material and thus modification of the redox processes involved, with a large participation of the $\mathrm{Mn}^{4+} / \mathrm{Mn}^{3+}$ redox couple at $3 \mathrm{~V}$ and thus a drastic shift of the average discharge potential. ${ }^{8,15}$ Figure 8c shows that playing with the cycling conditions of $800^{\circ} \mathrm{C}-5 \%$ it is possible to reach a good cyclability upon long range cycling, even if the discharge capacity remains $10 \%$ lower than that observed for LMN at $\mathrm{C} / 10$. Similar results were obtained for $900^{\circ} \mathrm{C}-5 \%$. Figure 9 shows also an interesting result obtained for these engineered materials varying the cycling rate in the voltage window $2.5-4.8 \mathrm{~V} \mathrm{vs.} \mathrm{Li}^{+} / \mathrm{Li}$ : a higher robustness versus $\mathrm{LMN}$ considering the capacity loss at high rates. $800^{\circ} \mathrm{C}-5 \%$ and $900^{\circ} \mathrm{C}-5 \%$ contain both a higher content in $\mathrm{Co}$ and $\mathrm{Ni}$ and a lower $\mathrm{Li} / \mathrm{M}$ ratio than LMN, they thus show as expected better transport properties. Indeed, the ordering between the $\mathrm{Li}^{+}$and $\mathrm{Mn}^{4+}$ cations within the slabs of the Li-rich layered oxides is highly detrimental to electronic and thus ionic mobility. The shell containing a concentration-gradient made of NMC-type layered oxides in $800^{\circ} \mathrm{C}-5 \%$ is in fact sufficient to improve the electrochemical behavior at high rate, despite a core of the aggregate ( $>50$ mol. $\%$ of the active material) made of the Li-rich phase LMN. For a global composition of the material $\mathrm{Li}_{1+\mathrm{x}}\left(\mathrm{Mn}_{0.47} \mathrm{Ni}_{0.26} \mathrm{Co}_{0.17}\right)_{1-\mathrm{x}} \mathrm{O}_{2}$, considering the transport properties it appears that the benefit of forming a shell richer in $\mathrm{Co}$ and in $\mathrm{Ni}$ as in $800^{\circ} \mathrm{C}-5 \%$ is higher than that observed by an average enrichment of the material $900^{\circ} \mathrm{C}-5 \%$. Indeed, the surface of the latter is poorer in Co and in Ni. Note that the average loss of capacity observed for the three materials is due to the large potential window used, as already discussed just before.

To summarize these results, the formation of engineered materials with Li-rich layered oxides in the core and NMC-type layered oxides in the shell has been achieved after an optimization of the synthesis protocol based on the coprecipitation of concentration-gradient carbonates. Even if these complex composites still suffer from the problem of voltage hysteresis and fading induced by local structural reorganization, ${ }^{7-9}$ they were shown to deliver interesting discharge capacity, cyclability and (especially) performance at high rates. 


\section{Conclusion}

In this study, we have successfully produced engineered lithium- and manganese-rich layered oxides. On the contrary to those formed at $700^{\circ} \mathrm{C}$ for Nickel-rich layered oxides ${ }^{12,14}$, the formation of concentration-gradients remains rather complex for Li-rich layered oxides. Indeed, calcination at high temperatures is required to promote the formation of ordered layered oxides and thus participation of the anion to the redox properties whereas, at these temperatures, diffusion of all the cations occurs within the solid and is detrimental to the formation of concentration-gradients. At $900^{\circ} \mathrm{C}$, homogenous materials (i.e. with a similar composition in transition metal ions in all the volume of the aggregates) are obtained whatever the excess of lithium used during the synthesis. At $800^{\circ} \mathrm{C}$, concentration-gradients are obtained within a shell, whose thickness increases with the lithium excess used during the synthesis.

We have also used a series of powerful techniques in order to precisely characterize these concentrationgradient materials: some of them give average information on the composition, structure and properties, as, for instance, XRD that allows identifying the nature of the phases formed (here either layered-types or, for $0 \%$ lithium excess, mixtures of layered and spinel-types). On the other hand, complementary techniques like EPMA analyses were used in order to get more insights into the extent of the concentration-gradient and on the transition metal ions distribution within the aggregates.

The formation of concentration-gradients into spherical aggregates of layered oxides has been shown to be inefficient to stabilize the material upon cycling and to prevent the voltage decay associated to cationic migration and formation of spinel-type domains induced by oxygen loss at its surface. Nevertheless, it was shown that engineered versus homogeneous compositions show good performance at high cycling rates, one of the main weakness of the Li-rich layered oxides. More efforts have now to be devoted to: $(i)$ define the better "formulation" for the engineered materials, i.e. for the shell the better choice of its thickness and composition, and of the extent of the gradient, and (ii) define the better cycling conditions in order to promote optimized performance for the core (Li-rich type) and for the shell (NMC-type).

\section{Acknowledgements}

The authors acknowledge Région Nouvelle Aquitaine for the funding of the overall project and especially of SP's PhD grant. The authors thank Philippe Dagault, Laëtitia Etienne and Eric Lebraud at ICMCB for their technical support for TGA, ICP-OES and XRD analyses, as well as Michel Lahaye and Pascale Garreta at PLACAMAT, the first for his scientific support with EPMA analyses and the second for the preparation of the cross polished samples. 


\section{References}

[1] M. M. Thackeray, S.-H. Kang, C. S. Johnson, J. T. Vaughey, R. Benedek, and S. A. Hackney, " $\mathrm{Li}_{2} \mathrm{MnO}_{3}$-stabilized $\mathrm{LiMO}_{2}(\mathrm{M}=\mathrm{Mn}, \mathrm{Ni}, \mathrm{Co})$ electrodes for lithium-ion batteries ", J. Mater. Chem., vol. 17, n 30, p. 3112-3125, April 2007.

[2] F. Zhou, X. Zhao, A. van Bommel, X. Xia, and J. R. Dahn, « Comparison of Li[Li $\left.\mathrm{Li}_{1 / 9} \mathrm{Ni}_{1 / 3} \mathrm{Mn}_{5 / 9}\right] \mathrm{O}_{2}$, $\mathrm{Li}\left[\mathrm{Li}_{1 / 5} \mathrm{Ni}_{1 / 5} \mathrm{Mn}_{3 / 5}\right] \mathrm{O}_{2}$, $\mathrm{LiNi}_{0.5} \mathrm{Mn}_{1.5} \mathrm{O}_{4}$, and $\mathrm{LiNi}_{2 / 3} \mathrm{Mn}_{1 / 3} \mathrm{O}_{2}$ as High Voltage Positive Electrode Materials », J. Electrochem. Soc., vol. 158, n² 2, p. A187, 2011.

[3] J. R. Croy, A. Abouimrane, and Z. Zhang, " Next-generation lithium-ion batteries: The promise of near-term advancements ", MRS Bull., vol. 39, n 05, p. 407-415, May 2014.

[4] H. Koga and al., " Reversible Oxygen Participation to the Redox Processes Revealed for $\mathrm{Li}_{1.20} \mathrm{Mn}_{0.54} \mathrm{Co}_{0.13} \mathrm{Ni}_{0.13} \mathrm{O}_{2}$ ", J. Electrochem. Soc., vol. 160, nº 6, p. A786-A792, March 2013.

[5] J. R. Croy, K. G. Gallagher, M. Balasubramanian, B. R. Long, and M. M. Thackeray, " Quantifying Hysteresis and Voltage Fade in $\mathrm{xLi}_{2} \mathrm{MnO}_{3} \bullet(1-\mathrm{x}) \mathrm{LiMn}_{0.5} \mathrm{Ni}_{0.5} \mathrm{O}_{2}$ Electrodes as a Function of $\mathrm{Li}_{2} \mathrm{MnO}_{3}$ Content », J. Electrochem. Soc., vol. 161, n 3, p. A318-A325, January 2014.

[6] M. Bettge and al., " Voltage Fade of Layered Oxides: Its Measurement and Impact on Energy Density ", J. Electrochem. Soc., vol. 160, n 11, p. A2046-A2055, January 2013.

[7] H. Koga, L. Croguennec, M. Ménétrier, P. Mannessiez, F. Weill, and C. Delmas, « Different oxygen redox participation for bulk and surface: A possible global explanation for the cycling mechanism of $\mathrm{Li}_{1.20} \mathrm{Mn}_{0.54} \mathrm{Co}_{0.13} \mathrm{Ni}_{0.13} \mathrm{O}_{2}$ ", J. Power Sources, vol. 236, p. 250-258, August 2013.

[8] A. Boulineau, L. Simonin, J.-F. Colin, C. Bourbon, and S. Patoux, « First Evidence of ManganeseNickel Segregation and Densification upon Cycling in Li-Rich Layered Oxides for Lithium Batteries ", Nano Lett., vol. 13, n 8, p. 3857-3863, August 2013.

[9] C. Genevois, H. Koga, L. Croguennec, M. Ménétrier, C. Delmas, and F. Weill, « Insight into the Atomic Structure of Cycled Lithium-Rich Layered Oxide $\mathrm{Li}_{1.20} \mathrm{Mn}_{0.54} \mathrm{Co}_{0.13} \mathrm{Ni}_{0.13} \mathrm{O}_{2}$ Using HAADF STEM and Electron Nanodiffraction ", J. Phys. Chem. C, vol. 119, n 1, p. 75-83, January 2015.

[10] Y.-K. Sun, S.-T. Myung, B.-C. Park, J. Prakash, I. Belharouak, and K. Amine, " High-energy cathode material for long-life and safe lithium batteries ", Nat. Mater., vol. 8, n ${ }^{\circ}$ 4, p. 320-324, April 2009.

[11] Y.-K. Sun, D.-H. Kim, C. S. Yoon, S.-T. Myung, J. Prakash, and K. Amine, « A Novel Cathode Material with a Concentration-Gradient for High-Energy and Safe Lithium-lon Batteries ", Adv. Funct. Mater., vol. 20, n 3, p. 485-491, February 2010.

[12] Y.-K. Sun, B.-R. Lee, H.-J. Noh, H. Wu, S.-T. Myung, and K. Amine, " A novel concentrationgradient $\mathrm{Li}\left[\mathrm{Ni}_{0.83} \mathrm{CO}_{0.07} \mathrm{Mn}_{0.10}\right] \mathrm{O}_{2}$ cathode material for high-energy lithium-ion batteries ", J. Mater. Chem., vol. 21, n 27, p. 10108, 2011.

[13] Y.-K. Sun and al., " Nanostructured high-energy cathode materials for advanced lithium batteries ", Nat. Mater., vol. 11, n 11, p. 942-947, November 2012.

[14] Y.-K. Sun, D.-H. Kim, H.-G. Jung, S.-T. Myung, and K. Amine, "High-voltage performance of concentration-gradient $\mathrm{Li}\left[\mathrm{Ni}_{0.67} \mathrm{CO}_{0.15} \mathrm{Mn}_{0.18}\right] \mathrm{O}_{2}$ cathode material for lithium-ion batteries ", Electrochimica Acta, vol. 55, n² 28, p. 8621-8627, December 2010.

[15] D. Peralta and al., " Role of the composition of lithium-rich layered oxide materials on the voltage decay ", J. Power Sources, vol. 280, p. 687-694, April 2015.

[16] D. Peralta, F. Fabre, P. Feydi, S. Martinet, M. Rey, and L. Simonin, « Matériaux d'électrode positive de batterie au lithium à base d'un oxyde lamellaire surlithié ", WO 2015/014807 A1, février-2015.

[17] R. Armstrong and al., " Demonstrating Oxygen Loss and Associated Structural Reorganization in the Lithium Battery Cathode $\mathrm{Li}_{[}\left[\mathrm{Ni}_{0,2} \mathrm{Li}_{0,2} \mathrm{Mn}_{0,6}\right] \mathrm{O}_{2}$ ", Journal of American Chemical Society, $\mathrm{p}$. 8694-8698, 2006.

[18] A. Boulineau, L. Croguennec, C. Delmas, and F. Weill, « Reinvestigation of $\mathrm{Li}_{2} \mathrm{MnO}_{3}$ Structure: Electron Diffraction and High Resolution TEM », Chem. Mater., vol. 21, n 18, p. 4216-4222, September 2009. 
[19] F. Weill, N. Tran, L. Croguennec, and C. Delmas, « Cation ordering in the layered $\mathrm{Li}_{1+x}\left[\mathrm{Ni}_{0.425} \mathrm{Mn}_{0.425} \mathrm{Co}_{0.15}\right]_{1-\mathrm{x}} \mathrm{O}_{2}$ materials ( $\mathrm{x}=0$ and 0.12 ) ", J. Power Sources, vol. 172, $\mathrm{n}^{\circ} 2$, p. 893900, October 2007.

[20] J. Bréger and al., " High-resolution X-ray diffraction, DIFFaX, NMR and first principles study of disorder in the $\mathrm{Li}_{2} \mathrm{MnO}_{3}-\mathrm{Li}\left[\mathrm{Ni}_{1 / 2} \mathrm{Mn}_{1 / 2}\right] \mathrm{O}_{2}$ solid solution ", J. Solid State Chem., vol. 178, n ${ }^{\circ}$ 9, p. 2575-2585, September 2005.

[21] M. Guilmard, A. Rougier, M. Grüne, L. Croguennec, and C. Delmas, " Effects of aluminum on the structural and electrochemical properties of $\mathrm{LiNiO}_{2}$ ", J. Power Sources, vol. 115, n 2, p. 305-314, April 2003.

[22] M. Guilmard, L. Croguennec, D. Denux, and C. Delmas, " Thermal Stability of Lithium Nickel Oxide Derivatives. Part I: $\mathrm{Li}_{x} \mathrm{Ni}_{1.02} \mathrm{O}_{2}$ and $\mathrm{Li}_{x} \mathrm{Ni}_{0.89} \mathrm{Al}_{0.16} \mathrm{O}_{2}(x=0.50$ and 0.30$)$ ", Chem. Mater., vol. 15, n 23, p. 4476-4483, November 2003.

[23] M. Guilmard, L. Croguennec, and C. Delmas, " Effects of Manganese Substitution for Nickel on the Structural and Electrochemical Properties of $\mathrm{LiNiO}_{2}$ ", J. Electrochem. Soc., vol. 150, n⿳ 10, p. A1287-A1293, January 2003.

[24] M. Guilmard, C. Pouillerie, L. Croguennec, and C. Delmas, « Structural and electrochemical properties of $\mathrm{LiNi}_{0.70} \mathrm{Co}_{0.15} \mathrm{Al}_{0.15} \mathrm{O}_{2}$ ", Solid State lon., vol. 160, n 1-2, p. 39-50, May 2003.

[25] J. Li, R. Shunmugasundaram, R. Doig, and J. R. Dahn, « In Situ X-ray Diffraction Study of Layered Li-Ni-Mn-Co Oxides: Effect of Particle Size and Structural Stability of Core-Shell Materials », Chem. Mater., vol. 28, n 1, p. 162-171, January 2016.

[26] J. Lin, D. Mu, Y. Jin, B. Wu, Y. Ma, and F. Wu, « Li-rich layered composite Li[ $\left[\mathrm{Li}_{0.2} \mathrm{Ni}_{0.2} \mathrm{Mn}_{0.6}\right] \mathrm{O}_{2}$ synthesized by a novel approach as cathode material for lithium ion battery ", J. Power Sources, vol. 230, p. 76-80, May 2013.

[27] H. Koga and al., " Operando X-ray Absorption Study of the Redox Processes Involved upon Cycling of the Li-Rich Layered Oxide $\mathrm{Li}_{1.20} \mathrm{Mn}_{0.54} \mathrm{Co}_{0.13} \mathrm{Ni}_{0.13} \mathrm{O}_{2}$ in Li-Ion Batteries ", J. Phys. Chem. C, vol. 118, no 11, p. 5700-5709, March 2014.

[28] Y. Xie, M. Saubanère, and M.-L. Doublet, « Requirements for reversible extra-capacity in Li-rich layered oxides for Li-ion batteries ", Energy Environ. Sci., vol. 10, nº 1, p. 266-274, January 2017.

[29] K. Luo and al., " Charge-compensation in 3d-transition-metal-oxide intercalation cathodes through the generation of localized electron holes on oxygen ", Nat. Chem., vol. 8, n 7, p. 684-691, March 2016.

[30] H. Koga, L. Croguennec, M. Ménétrier, P. Mannessiez, F. Weill, C. Delmas, and S. Belin, " $\mathrm{Li}_{1.20} \mathrm{Mn}_{0.54} \mathrm{Co}_{0.13} \mathrm{Ni}_{0.13} \mathrm{O}_{2}$ with Different Particle Sizes as Attractive Positive Electrode Materials for Lithium-Ion Batteries: Insights into Their Structure ॥, J. Phys. Chem. C, vol. 118, n 11, p. 5700-5709, February 2014.

[31] L. Croguennec, C. Pouillerie, A.N. Mansour and C. Delmas, "Structural characterization of the highly deintercalated $\mathrm{Li}_{x} \mathrm{Ni}_{1.02} \mathrm{O}_{2}$ phases (with $\mathrm{x} \leq 0.3$ ) ", J. Mater. Chem., vol. 11, p. 131-141, 2001. 


\section{Table captions}

Table 1: The molar contents in $\mathrm{Ni}, \mathrm{Mn}$ and Co determined by ICP-OES analyses are given for the supernatant and for the carbonate and compared for that latter to the theoretical values calculated from equation (3). The results of TGA analyses are also reported and compared to the theoretical value.

Table 2: Comparison of the crystallinity of different full concentration gradient lithiated layered oxides with that of the homogeneous layered oxide $\mathrm{Li}_{1.2} \mathrm{Mn}_{0.6} \mathrm{Ni}_{0.2} \mathrm{O}_{2}$, considering changes in the full width at half maximum for different diffraction lines. The cationic chemical composition determined by ICP for each sample is also given, considering $\mathrm{Li}_{1+x} \mathrm{M}_{1-\mathrm{x}}$ with $\Sigma(\mathrm{Li}+\mathrm{M})=2$.

Table 3: Comparison of the lattice parameters and confident factors determined for the "phase(s)" identified in the full concentration-gradient materials with those determined for the homogeneous layered oxide $\mathrm{Li}_{1.2} \mathrm{Mn}_{0.6} \mathrm{Ni}_{0.2} \mathrm{O}_{2}$.

Table 4: Comparison of the electrochemical performances obtained for different materials synthesized at $700^{\circ} \mathrm{C}, 800^{\circ} \mathrm{C}$ and $900^{\circ} \mathrm{C}$ with different lithium excesses $(5 \%$ and $20 \%$ ) with those determined for the homogeneous layered oxide $\mathrm{Li}_{1.2} \mathrm{Mn}_{0.6} \mathrm{Ni}_{0.2} \mathrm{O}_{2}$. Electrochemical performance obtained at the rate of $\mathrm{C} / 10$ in lithium cells in the voltage range 4.8-2.5 V. The deviation on the values was calculated based on 4 different cells cycled in exactly the same conditions, it allows to highlight the reproducibility of the experiments and to support the relationship drawn from on sample to another between the synthesis conditions, the nature of the material obtained and its electrochemical behavior. 
Pajot et al., submitted to JES

Table 1

\begin{tabular}{|c|c|c|c|c|c|}
\hline & & $\begin{array}{c}\text { Ni content (mol) } \\
\text { Molar fraction (\%) }\end{array}$ & $\begin{array}{l}\text { Mn content (mol) } \\
\text { Molar fraction (\%) }\end{array}$ & $\begin{array}{l}\text { Co content (mol) } \\
\text { Molar fraction (\%) }\end{array}$ & $\begin{array}{c}\text { Mass loss } \\
(\%)\end{array}$ \\
\hline \multirow{4}{*}{$\begin{array}{l}\text { ICP-OES } \\
\text { analyses }\end{array}$} & Supernatant & $\begin{array}{c}0.0018( \pm 4) \\
1.06\end{array}$ & $\begin{array}{c}0.0005( \pm 2) \\
0.17\end{array}$ & $\begin{array}{c}0.00032( \pm 2) \\
0.31\end{array}$ & \\
\hline & Carbonate powder & $0.17( \pm 2)$ & $0.290( \pm 8)$ & $0.103( \pm 1)$ & \\
\hline & Experimental total & 0.17 & 0.290 & 0.103 & \\
\hline & Theoretical total & 0.18 & 0.328 & 0.112 & \\
\hline \multirow{2}{*}{ TGA analyses } & Experimental & & 36 \\
\hline & Theoretical & & & & 37.5 \\
\hline
\end{tabular}


Pajot et al., submitted to JES

Table 2

\begin{tabular}{|c|c|c|c|c|}
\hline \multirow{2}{*}{ Materials } & \multicolumn{2}{|c|}{ FWHM $\left({ }^{\circ}(2 \theta)\right)$} & \multirow{2}{*}{ Ratio $\left.I_{(003)}\right)_{(104)}$} & \multirow{2}{*}{ Actual composition* } \\
\hline & (018) & (110) & & \\
\hline$L M N$ & 0.33 & 0.28 & 1.07 & $\mathrm{Li}^{+}{ }_{1.22} \mathrm{Ni}^{2+}{ }_{0}{ }_{16} \mathrm{Ni}^{3+}{ }_{0}{ }_{0} .3 \mathrm{Mn}^{4+}{ }_{0}{ }_{0.60}$ \\
\hline $900^{\circ} \mathrm{C}-20 \%$ & 0.66 & 0.27 & 0.96 & $\mathrm{Li}^{+}{ }_{1.10} \mathrm{Ni}^{2+}{ }_{0.25} \mathrm{Mn}^{3+}{ }_{0.03} \mathrm{Mn}^{4+}{ }_{0.45} \mathrm{Co}^{3+}{ }_{0.16}$ \\
\hline $900^{\circ} \mathrm{C}-5 \%$ & 0.41 & 0.23 & 1.01 & $\mathrm{Li}^{+}{ }_{1.06} \mathrm{Ni}^{2+}{ }_{0.26} \mathrm{Mn}^{3+}{ }_{0.13} \mathrm{Mn}^{4+}{ }_{0.38} \mathrm{Co}^{3+}{ }_{0.17}$ \\
\hline $900^{\circ} \mathrm{C}-0 \%$ & 0.29 & 0.18 & 1.42 & $\mathrm{Li}^{+}{ }_{1.05} \mathrm{Ni}^{2+}{ }_{0.28} \mathrm{Mn}^{3+}{ }_{0.12} \mathrm{Mn}^{4+}{ }_{0.37} \mathrm{Co}^{3+}{ }_{0.18}$ \\
\hline $800^{\circ} \mathrm{C}-20 \%$ & 0.29 & 0.43 & 0.95 & $\mathrm{Li}^{+}{ }_{1.13} \mathrm{Ni}^{2+}{ }_{0.22} \mathrm{Ni}^{3+} 0.02 \mathrm{Mn}^{4+}{ }_{0.48} \mathrm{Co}^{3+}{ }_{0.15}$ \\
\hline $800^{\circ} \mathrm{C}-5 \%$ & 0.46 & 0.43 & 1.07 & $\mathrm{Li}^{+}{ }_{1.07} \mathrm{Ni}^{2+}{ }_{0.26} \mathrm{Mn}^{3+}{ }_{0.11} \mathrm{Mn}^{4+}{ }_{0.40} \mathrm{CO}^{3+}{ }_{0.17}$ \\
\hline $800^{\circ} \mathrm{C}-0 \%$ & 0.34 & 0.30 & 1.14 & $\mathrm{Li}^{+}{ }_{1.04} \mathrm{Ni}^{2+}{ }_{0.26} \mathrm{Mn}^{3+}{ }_{0.18} \mathrm{Mn}^{4+}{ }_{0.35} \mathrm{Co}^{3+}{ }_{0.17}$ \\
\hline $700^{\circ} \mathrm{C}-20 \%$ & \multicolumn{2}{|c|}{1.26} & 0.35 & $\mathrm{Li}^{+}{ }_{1.12} \mathrm{Ni}^{2+}{ }_{0.23} \mathrm{Ni}^{3+}{ }_{0.02} \mathrm{Mn}^{4+}{ }_{0.47} \mathrm{Co}^{3+}{ }_{0.16}$ \\
\hline $700^{\circ} \mathrm{C}-5 \%$ & \multicolumn{2}{|c|}{1.16} & 0.78 & $\mathrm{Li}^{+}{ }_{1.08} \mathrm{Ni}^{2+}{ }_{0.25} \mathrm{Mn}^{3+}{ }_{0.09} \mathrm{Mn}^{4+}{ }_{0.42} \mathrm{Co}^{3+}{ }_{0.16}$ \\
\hline $700^{\circ} \mathrm{C}-0 \%$ & 0.69 & 0.93 & 0.80 & $\mathrm{Li}^{+}{ }_{1.03} \mathrm{Ni}^{2+}{ }_{0.27} \mathrm{Mn}^{3+}{ }_{0.20} \mathrm{Mn}^{4+}{ }_{0.33} \mathrm{Co}^{3+}{ }_{0.17}$ \\
\hline
\end{tabular}


Table 3

\begin{tabular}{|c|c|c|c|c|c|c|c|}
\hline \multirow{2}{*}{ Materials } & \multirow{2}{*}{$\begin{array}{l}\text { Phase type } \\
\text { (space group) }\end{array}$} & $a=b(\AA)$ & $c(\AA)$ & \multirow{2}{*}{$c / a$} & \multirow{2}{*}{$V\left(\AA^{3}\right)$} & \multirow{2}{*}{$\begin{array}{l}R_{w p} \\
(\%)\end{array}$} & \multirow{2}{*}{$x^{2}$} \\
\hline & & \multicolumn{2}{|c|}{$a=b=c(\AA)$} & & & & \\
\hline$L M N$ & Layered $(R \overline{3} m)$ & $2.8578(8)$ & $14.250(4)$ & 4.99 & $100.79(5)$ & 15.8 & 3.67 \\
\hline $900^{\circ} \mathrm{C}-20 \%$ & Layered $(R \overline{3} m)$ & $2.8541(2)$ & $14.217(1)$ & 4.98 & $100.29(1)$ & 12.7 & 2.54 \\
\hline $900^{\circ} \mathrm{C}-5 \%$ & Layered $(R \overline{3} m)$ & $2.8591(3)$ & $14.239(2)$ & 4.98 & $100.80(2)$ & 16.3 & 2.44 \\
\hline \multirow{2}{*}{$900^{\circ} \mathrm{C}-0 \%$} & Layered $(R \overline{3} m)$ & $2.8578(5)$ & $14.268(4)$ & 4.99 & $100.92(4)$ & \multirow{2}{*}{19.6} & \multirow{2}{*}{3.02} \\
\hline & Spinel $(F d \overline{3} m)$ & \multicolumn{2}{|c|}{$8.139(1)$} & - & $539.1(2)$ & & \\
\hline $800^{\circ} \mathrm{C}-20 \%$ & Layered $(R \overline{3} m)$ & $2.8516(2)$ & 14.195(1) & 4.98 & $99.96(2)$ & 17.7 & 2.37 \\
\hline $800^{\circ} \mathrm{C}-5 \%$ & Layered $(R \overline{3} m)$ & $2.8570(5)$ & $14.227(2)$ & 4.98 & $100.57(3)$ & 16.0 & 1.74 \\
\hline \multirow{2}{*}{$800^{\circ} \mathrm{C}-0 \%$} & Layered $(R \overline{3} m)$ & $2.8557(3)$ & $14.242(3)$ & 4.99 & $100.58(3)$ & \multirow{2}{*}{21.2} & \multirow{2}{*}{1.68} \\
\hline & Spinel $(F d \overline{3} m)$ & \multicolumn{2}{|c|}{ 8.207(4) } & - & $552.7(4)$ & & \\
\hline $700^{\circ} \mathrm{C}-20 \%$ & Layered $(R \overline{3} m)$ & $2.8567(7)$ & $14.155(7)$ & 4.95 & $100.78(7)$ & 26.2 & 1.83 \\
\hline $700^{\circ} \mathrm{C}-5 \%$ & Layered $(R \overline{3} m)$ & $2.858(1)$ & $14.228(5)$ & 4.98 & $100.65(6)$ & 19.9 & 1.26 \\
\hline \multirow{2}{*}{$700^{\circ} \mathrm{C}-0 \%$} & Layered $(R \overline{3} m)$ & $2.8543(4)$ & $14.239(4)$ & 4.99 & $100.46(3)$ & \multirow{2}{*}{21.7} & \multirow{2}{*}{1.77} \\
\hline & Spinel $(F d \overline{3} m)$ & \multicolumn{2}{|c|}{$8.272(2)$} & - & $566.0(3)$ & & \\
\hline
\end{tabular}


Pajot et al., submitted to JES

Table 4

\begin{tabular}{|c|c|c|c|c|c|}
\hline Materials & $\begin{array}{l}1^{\text {st }} \text { charge } \\
\text { capacity } \\
\text { (mAh/g) }\end{array}$ & $\begin{array}{c}1 \text { st discharge } \\
\text { capacity } \\
\text { (mAh/g) }\end{array}$ & $\begin{array}{c}60^{\text {th }} \text { discharge } \\
\text { capacity } \\
\text { (mAh/g) }\end{array}$ & $\begin{array}{c}1 \text { st average } \\
\text { disc. Voltage } \\
\text { (V) }\end{array}$ & $\begin{array}{c}60^{\text {th }} \text { average } \\
\text { disc. Voltage } \\
\text { (V) }\end{array}$ \\
\hline$L M N$ & $302(6)$ & $234(4)$ & $221(7)$ & $3.58(2)$ & $3.46(1)$ \\
\hline $900^{\circ} \mathrm{C}-20 \%$ & $311(4)$ & $232(4)$ & 203(4) & $3.72(1)$ & $3.56(1)$ \\
\hline $900^{\circ} \mathrm{C}-5 \%$ & 288(9) & $230(7)$ & $216(7)$ & $3.78(1)$ & $3.52(1)$ \\
\hline $800^{\circ} \mathrm{C}-20 \%$ & $294(4)$ & $210(4)$ & $151(4)$ & $3.70(1)$ & $3.40(1)$ \\
\hline $800^{\circ} \mathrm{C}-5 \%$ & $297(5)$ & $242(5)$ & $178(5)$ & $3.67(1)$ & $3.43(2)$ \\
\hline $700^{\circ} \mathrm{C}-20 \%$ & 242(4) & $181(6)$ & $104(6)$ & $3.62(2)$ & $3.22(2)$ \\
\hline $700^{\circ} \mathrm{C}-5 \%$ & $274(9)$ & $211(9)$ & $123(5)$ & $3.66(2)$ & $3.27(2)$ \\
\hline
\end{tabular}




\section{Figure captions}

Figure 1: Description of the setup used to prepare the carbonate spherical aggregates with a concentration-gradients by co-precipitation.

Figure 2: Evolution of the mole fraction $\mathrm{t}_{\mathrm{m}}$ of $\mathrm{Ni}, \mathrm{Mn}$ and $\mathrm{Co}$ as function of time. The composition at $\mathrm{t}$ $=0\left(\mathrm{Ni}_{0.25} \mathrm{Mn}_{0.75} \mathrm{CO}_{3}\right)$ gives the mole fractions of the transition metal ions in the solution $\mathrm{A}\left(\mathrm{t}_{\mathrm{m}} \mathrm{Ni}=0.25\right.$ $\left.; \mathrm{t}_{\mathrm{m}} \mathrm{Mn}=0.75 ; \mathrm{t}_{\mathrm{m}} \mathrm{Co}=0\right)$. The final composition corresponds to $\mathrm{Ni}_{0.29} \mathrm{Mn}_{0.53} \mathrm{Co}_{0.18} \mathrm{CO}_{3}\left(\mathrm{t}_{\mathrm{m}} \mathrm{Ni}=0.29\right.$; $\left.\mathrm{t}_{\mathrm{m}} \mathrm{Mn}=0.53 ; \mathrm{t}_{\mathrm{m}} \mathrm{Co}=0.18\right)$.

Figure 3: XRD pattern recorded for a full concentration gradient carbonate (a), with the corresponding SEM images at low- and high-magnifications (b-c).

Figure 4: Image of the cross-section of the electrode made of the active material, divided carbon and PVdF (a) and corresponding changes in composition in Nickel, Manganese and Cobalt observed by EPMA (b).

Figure 5: Comparison of the XRD patterns of the lithiated oxides, calcined at $700^{\circ} \mathrm{C}, 800^{\circ} \mathrm{C}$ and $900^{\circ} \mathrm{C}$ with different lithium excesses $(0 \%, 5 \%$ and $20 \%)$, with that of the homogeneous layered oxide $\mathrm{Li}_{1.2} \mathrm{Mn}_{0.6} \mathrm{Ni}_{0.2} \mathrm{O}_{2}$ (LMN) (a). An enlargement in the angular range of $61-66.5^{\circ}$ is also given in (b): the dashed line and the star indicate a diffraction line associated to the formation of a spinel-type structure.

Figure 6: Compositional changes determined by EPMA for different materials synthesized at $700^{\circ} \mathrm{C}$ and $800{ }^{\circ} \mathrm{C}$ with different lithium excesses $(0 \%, 5 \%$ and $20 \%)$. As previously described a series of cut spherical aggregates were analyzed within an electrode cross-section. An example of aggregates is given in insert for each sample.

Figure 7: Electrochemical performance obtained at the rate of $\mathrm{C} / 10$ in lithium cells for the layered oxide type engineered materials, in comparison with those of the homogeneous layered oxide $\mathrm{Li}_{1.2} \mathrm{Mn}_{0.6} \mathrm{Ni}_{0.2} \mathrm{O}_{2}$ (LMN): (a) initial charge-discharge cycles, (b) discharge capacity as function of the number of cycles and (c) change in the discharge average potential in the voltage range $4.8-2.5 \mathrm{~V}$ as function of the number of cycles.

Figure 8: Electrochemical performance obtained at the rate of $\mathrm{C} / 10$ in lithium cells for the layered oxide type engineered material prepared at $800^{\circ} \mathrm{C}$ with a lithium excess of $5 \mathrm{wt} . \%\left(\mathbf{8 0 0}^{\circ} \mathbf{C - 5 \%}\right)$, depending on the voltage window used: $2.5-4.8 \mathrm{~V}$ for all cycles (black), $2.5-4.8 \mathrm{~V}$ only for the first cycle and then $2.5-4.55 \mathrm{~V}$ (blue), or $2.5-4.55 \mathrm{~V}$ for all cycles (red). (a) gives the comparison of the first two chargedischarge cycles. (b) compares the derivative curves of the $1^{\text {st }}$ and $60^{\text {th }}$ cycles (in continuous and dotted lines respectively). (c) gives the change in the discharge capacity and coulombic efficiency as function of the number of cycles and (d) that in the discharge average potential as function of the number of cycles.

Figure 9: Discharge capacity as function of the number of cycles, obtained in lithium cells in the 2.5 $4.8 \mathrm{~V}$ potential window varying the cycling rate: the layered oxide type engineered materials synthesized at $800^{\circ} \mathrm{C}$ and $900^{\circ} \mathrm{C}$ with a lithium excess of $5 \mathrm{wt} . \%\left(\mathbf{8 0 0}^{\circ} \mathbf{C}-5 \%\right.$ and $\left.900{ }^{\circ} \mathbf{C}-5 \%\right)$ are compared with the homogeneous layered oxide $\mathrm{Li}_{1.2} \mathrm{Mn}_{0.6} \mathrm{Ni}_{0.2} \mathrm{O}_{2}(\mathbf{L M N})$. 


\section{Figure 1}

(Please, consider that this figure requires to be included as a two columns figure)

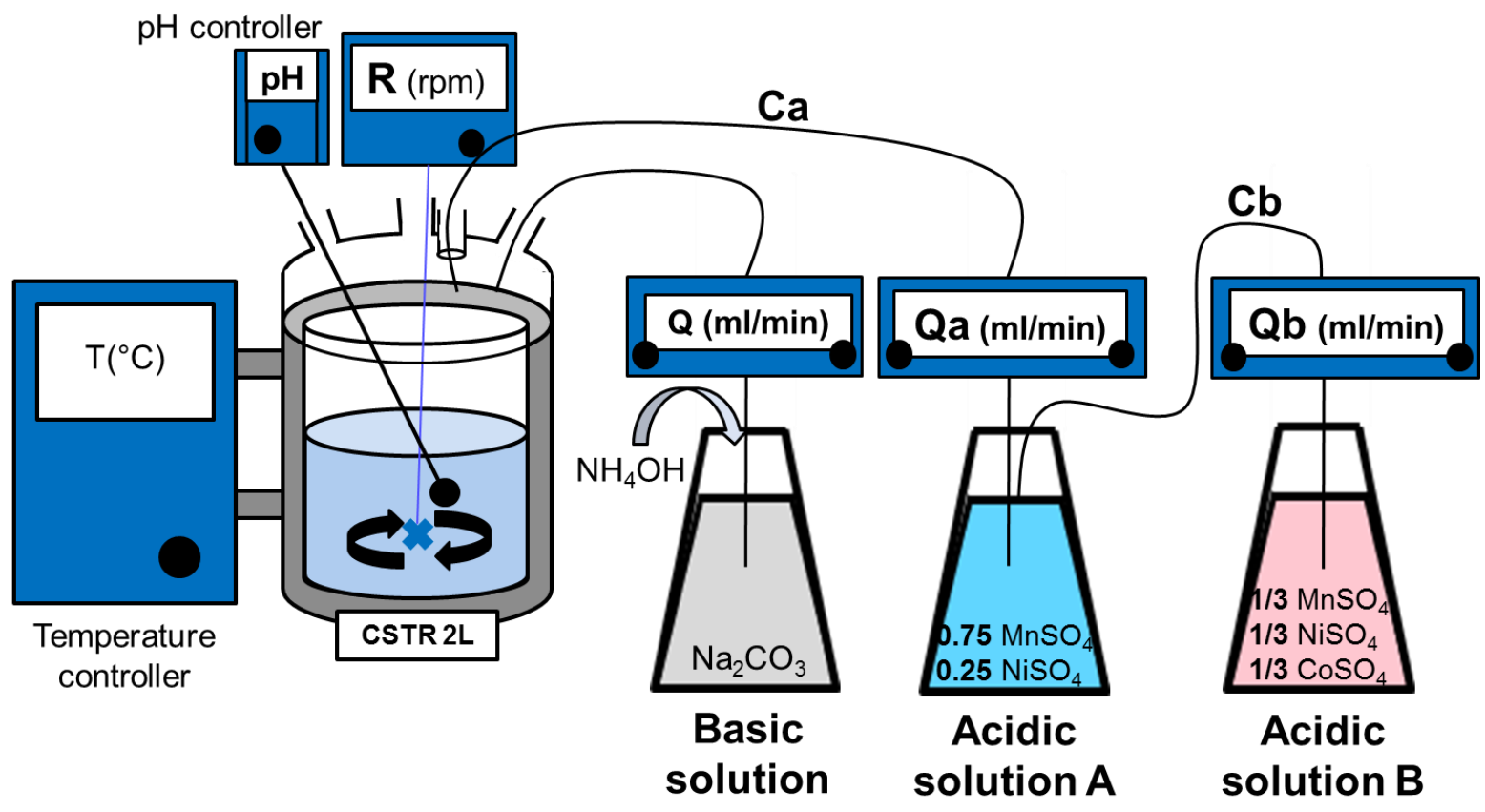


Figure 2

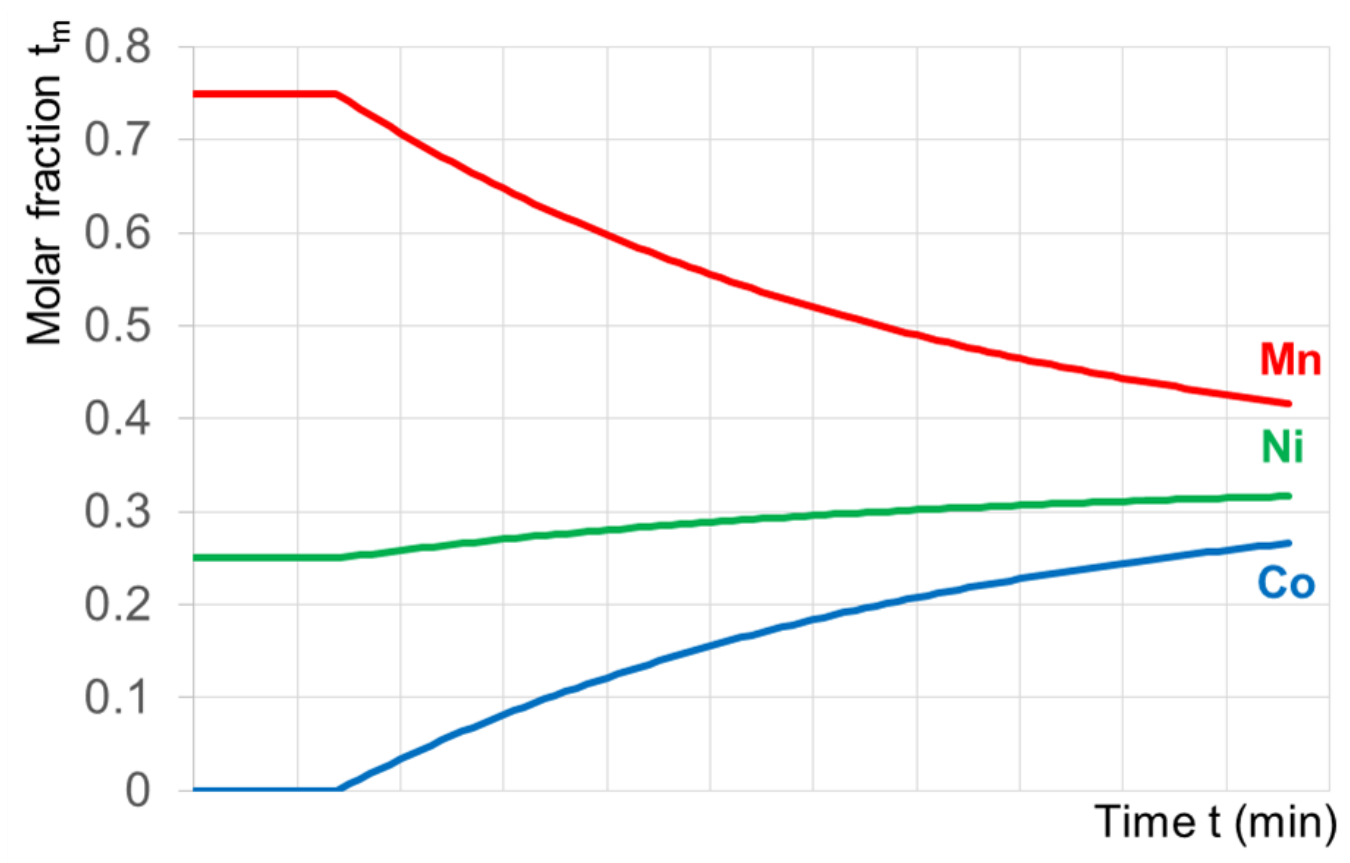


Figure 3

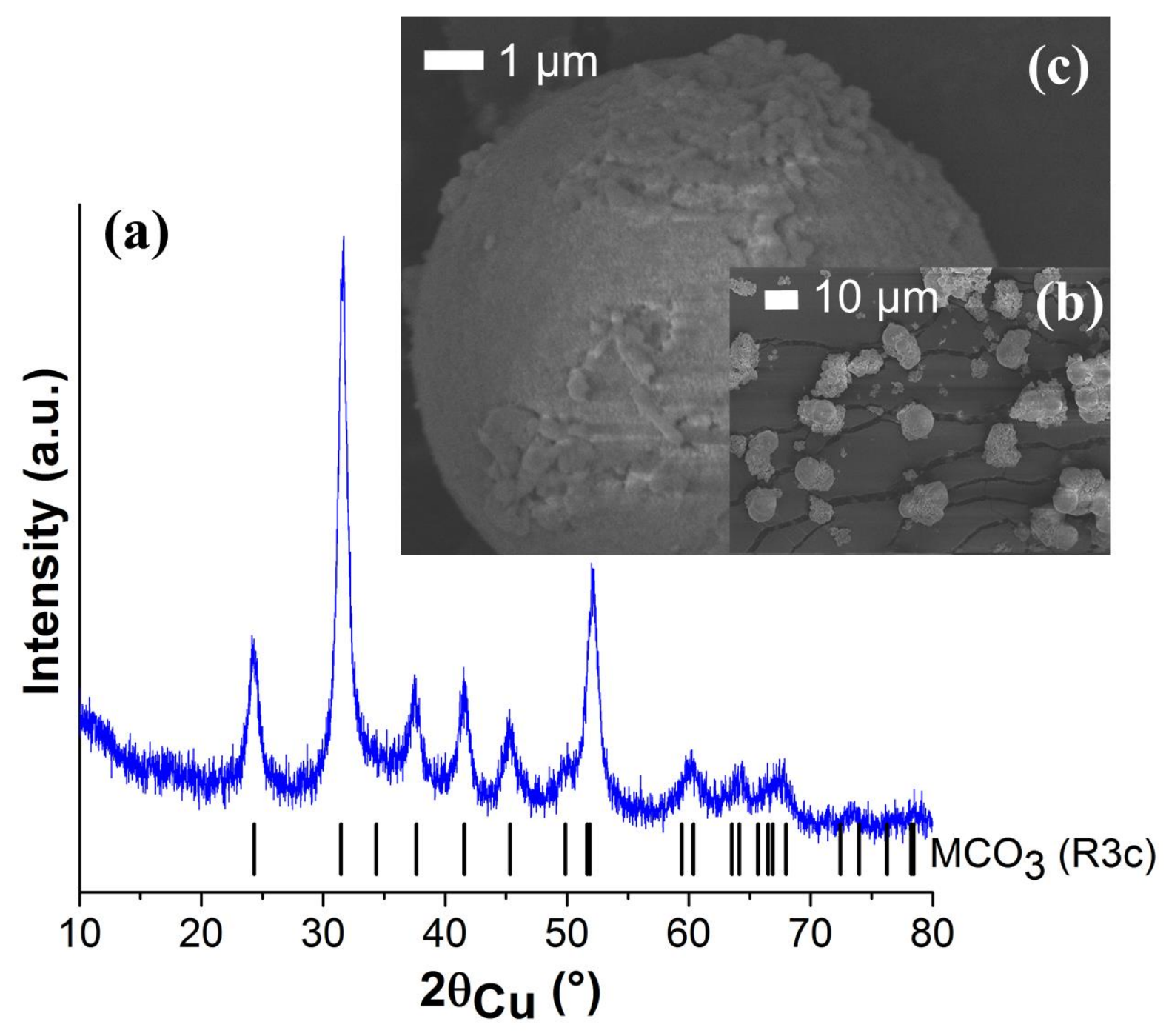


Figure 4

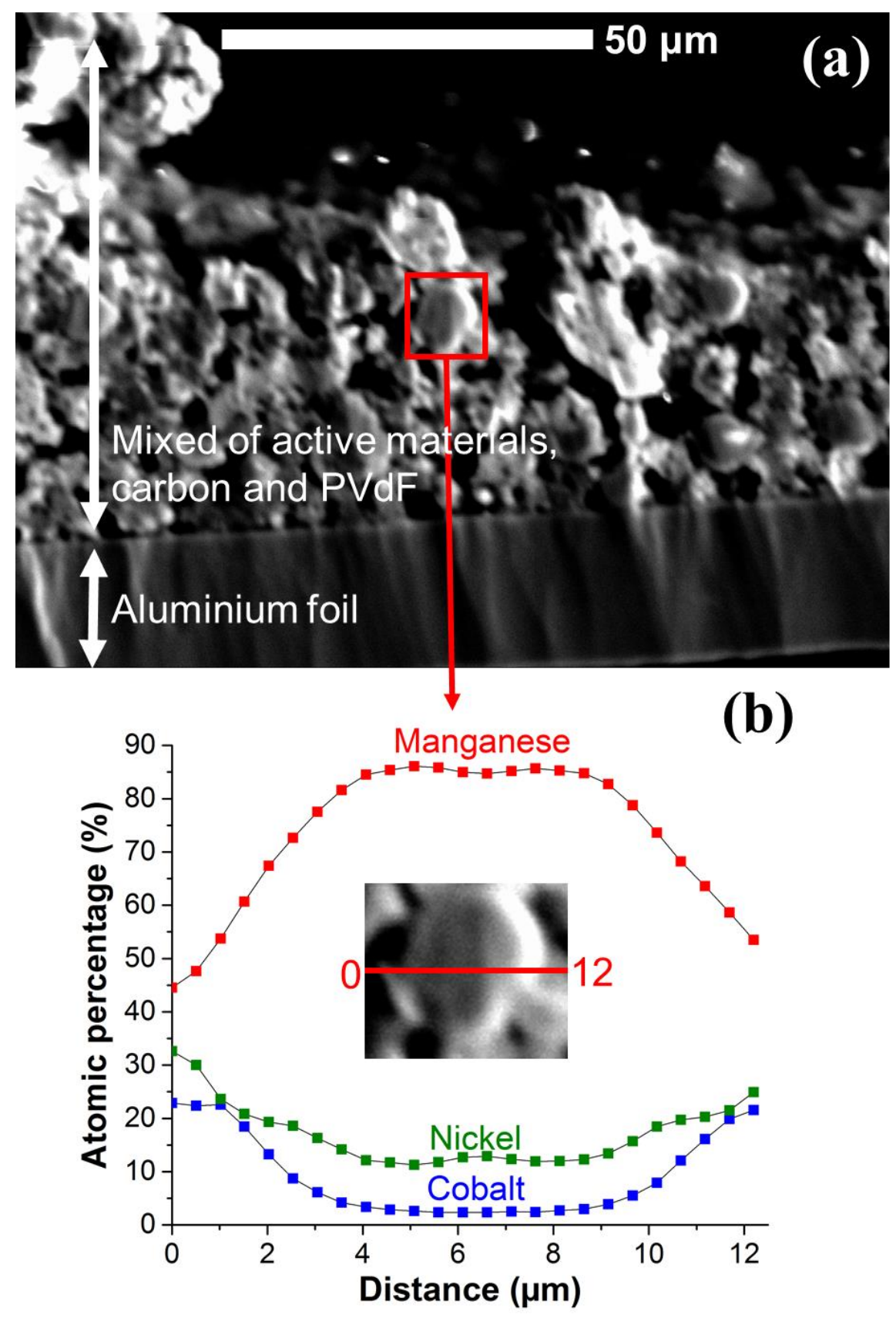




\section{Figure 5}
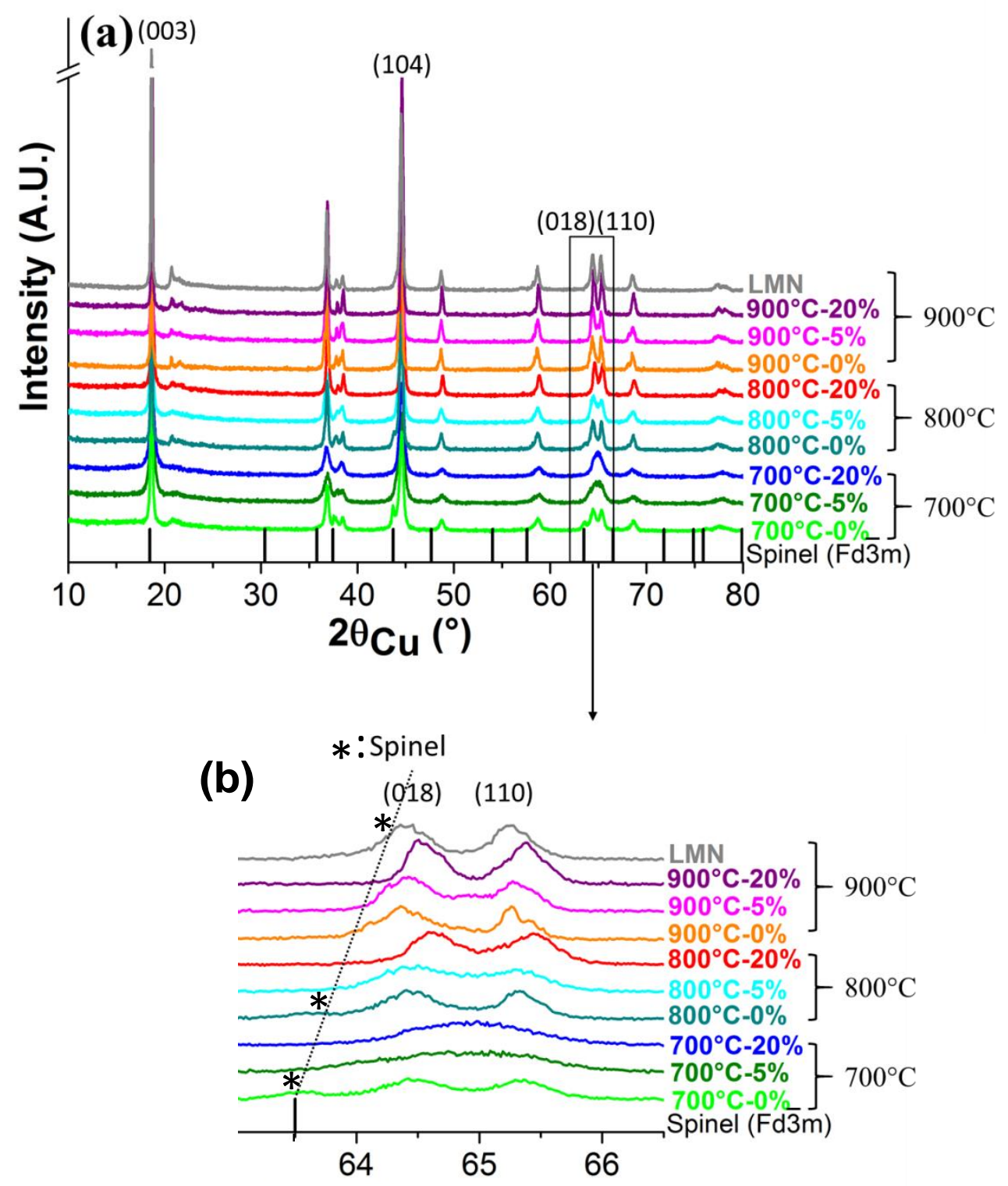
Pajot et al., submitted to JES

\section{Figure 6}

(Please, consider that this figure requires to be included as a two columns figure)

(a) $700{ }^{\circ} \mathrm{C}-0 \%$

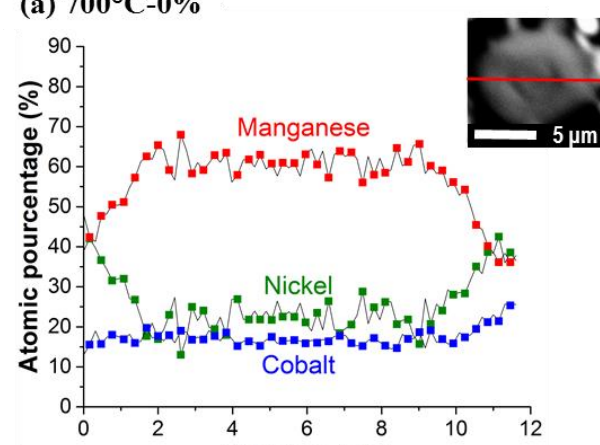

(b) $700{ }^{\circ} \mathrm{C}-5 \%$ Distance $(\mu \mathrm{m})$

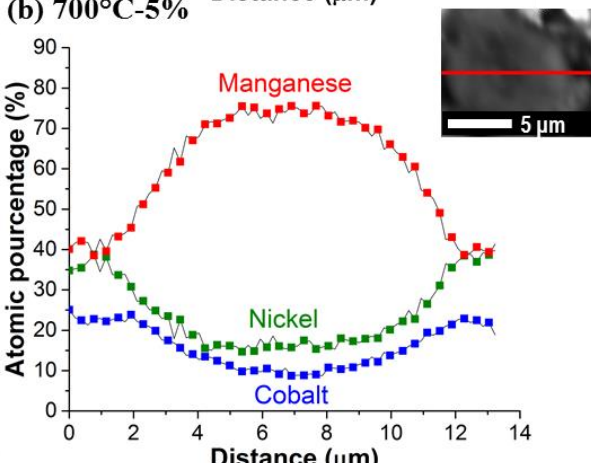

(c) $700{ }^{\circ} \mathrm{C}-20 \%$

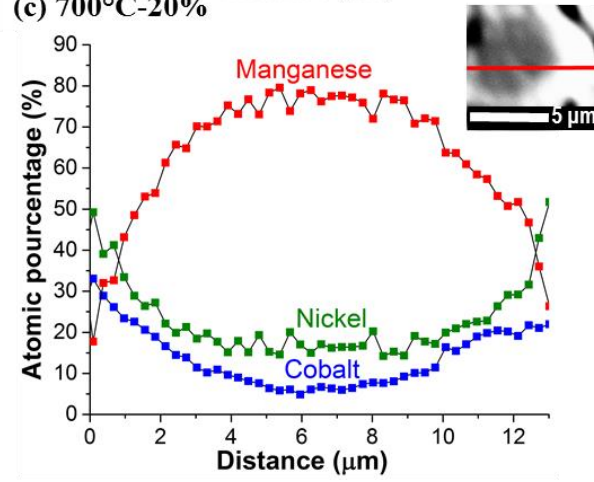

(d) $800^{\circ} \mathrm{C}-0 \%$

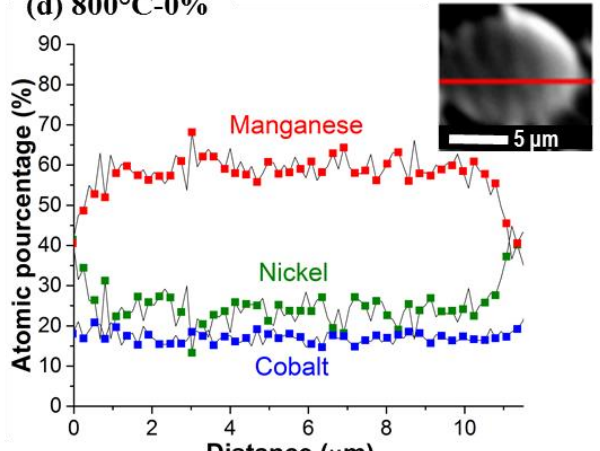

(e) $800^{\circ} \mathrm{C}-5 \%$ Distance $(\mu \mathrm{m})$

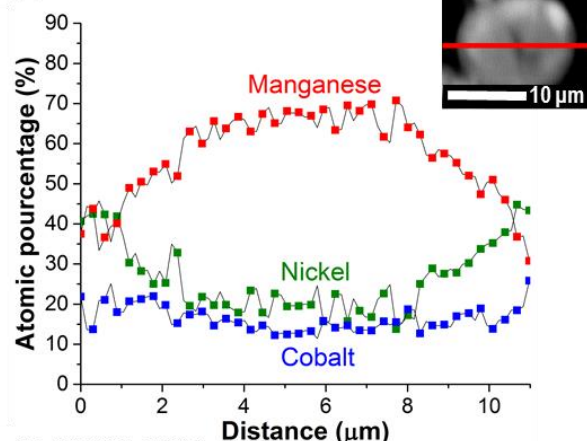

(f) $800{ }^{\circ} \mathrm{C}-20 \%$

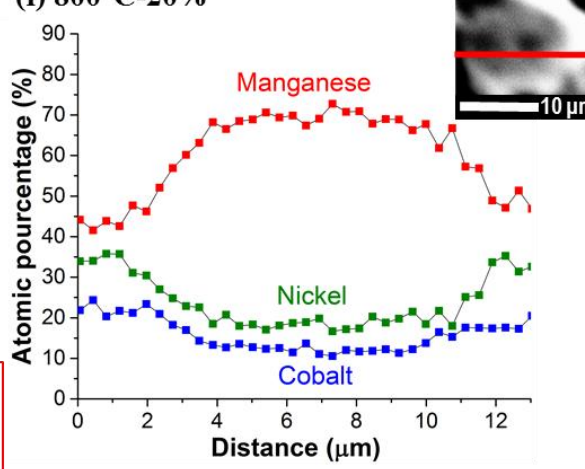


Figure 7
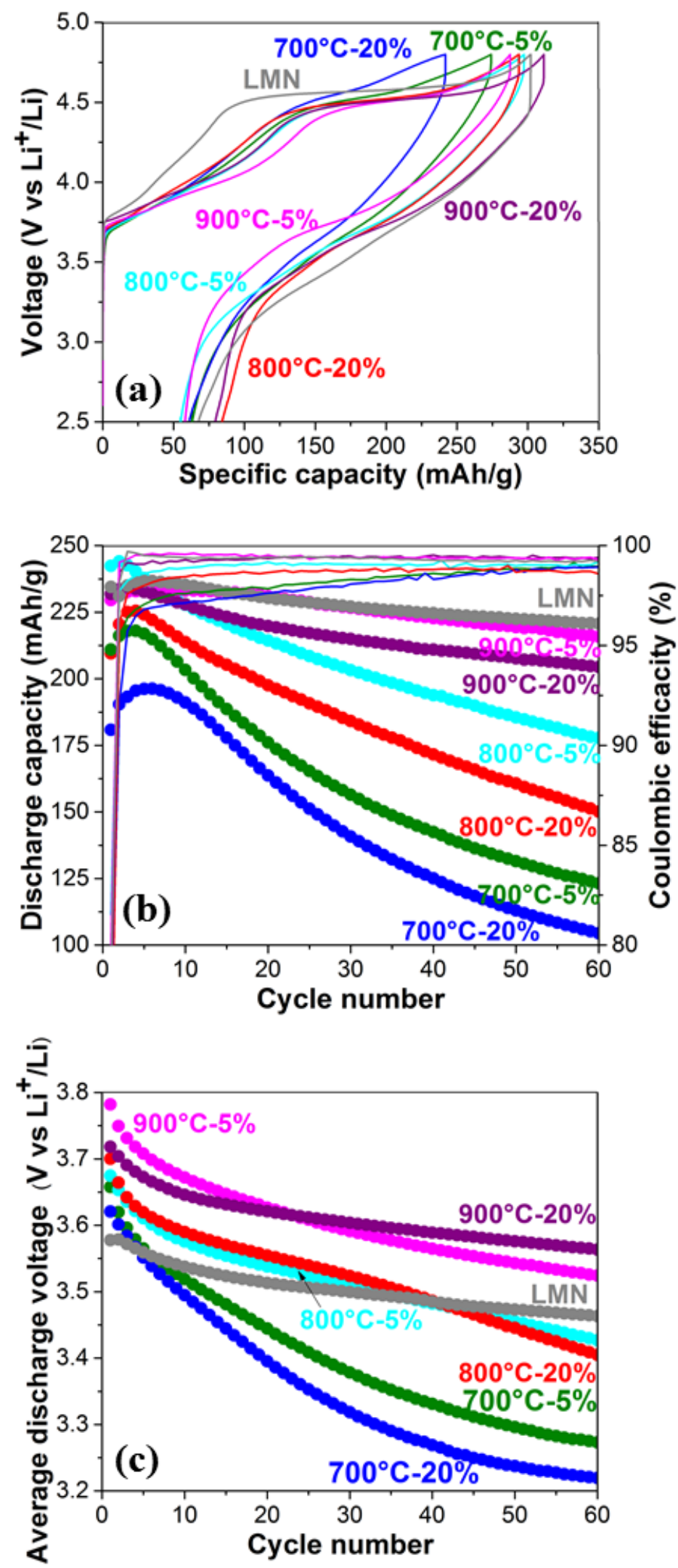
Pajot et al., submitted to JES

\section{Figure 8}

(Please, consider that this figure requires to be included as a two columns figure)
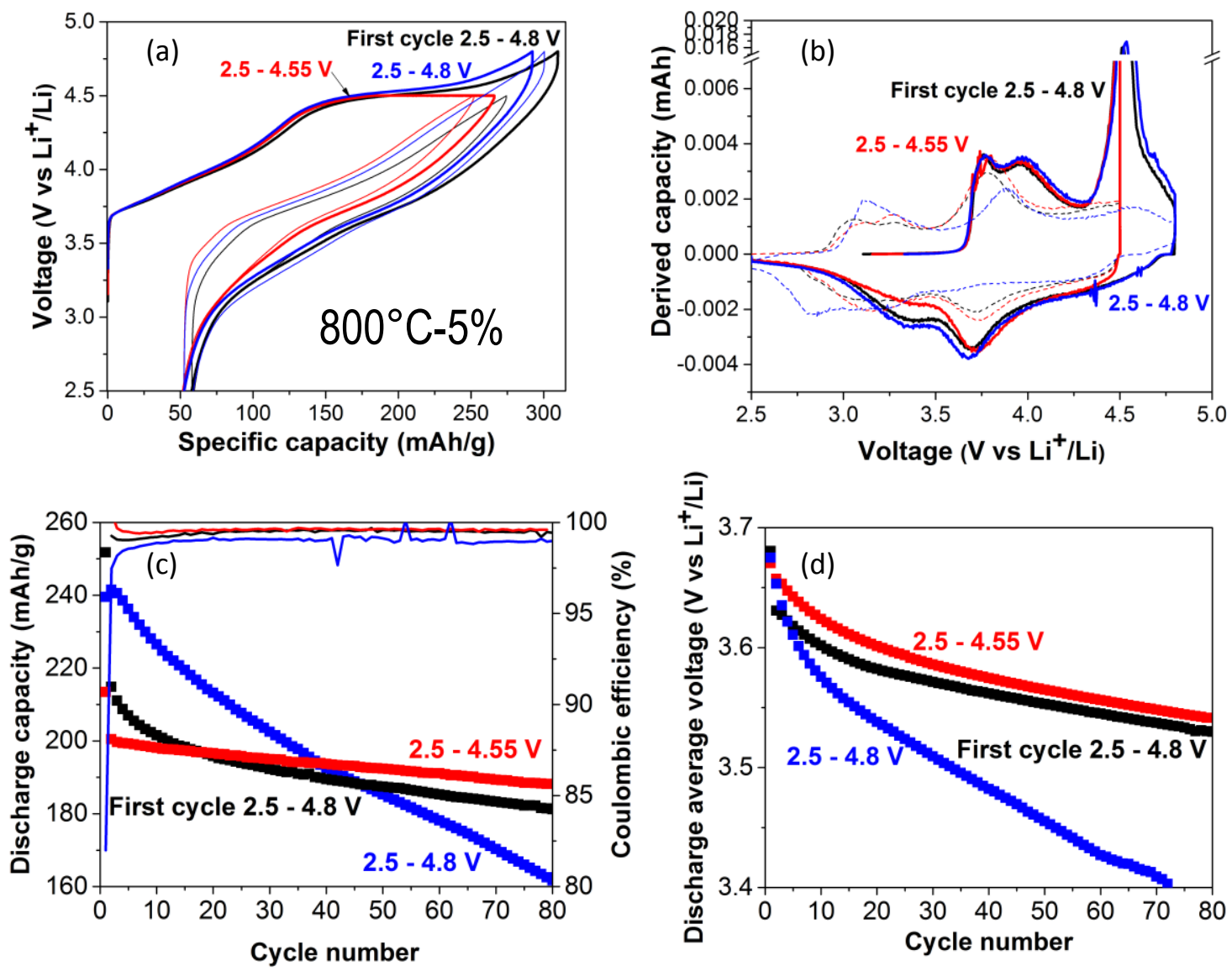
Figure 9

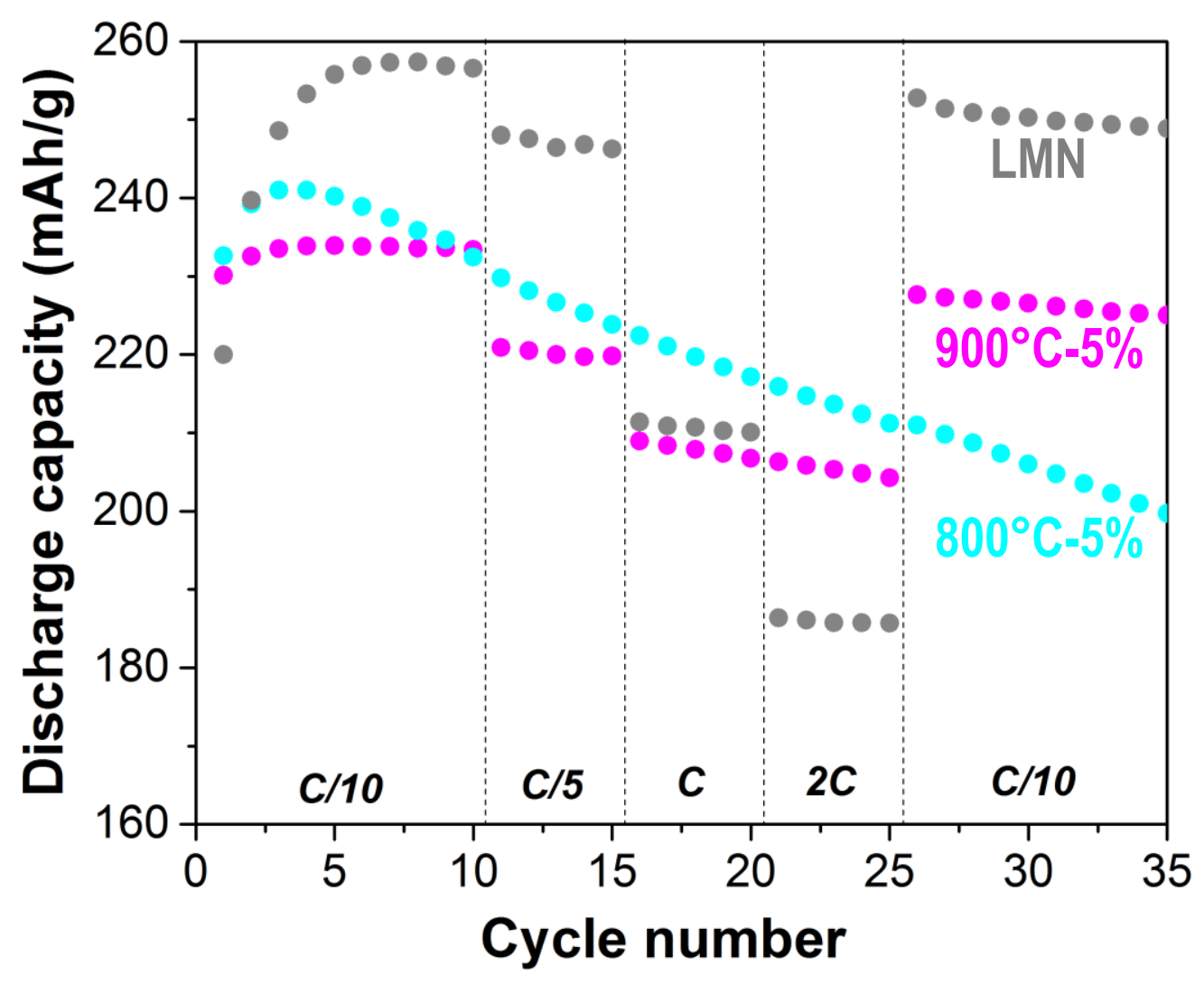

